\title{
ESTUDO DA EFICIÊNCIA DE DOIS MÉTODOS DE AMOSTRAGEM DE ÁRVORES DE RUA NA CIDADE DE SÃO CARLOS - SP
}

\author{
CAROLINA RACHID \\ Engenheira Florestal
}

Orientador: Prof. Dr. HILTON THADEU ZARATE DO COUTO

Dissertação apresentada à Escola Superior de Agricultura "Luiz de Queiroz", Universidade de São Paulo, para obtenção do título de Mestre em Ciências, Área de Concentração: Ciências Florestais.

\author{
P I R A C I C A B A \\ Estado de São Paulo - Brasil
}

Abril - 1999 
Dados Internacionais de Catalogação na Publicação (CIP) DIVISÃO DE BIBLIOTECA E DOCUMENTAÇÃO - Campus "Luiz de Queiroz"/USP

Rachid, Carolina

Estudo da eficiência de dois métodos de amostragem de árvores de rua na cidade de São Carlos - SP / Carolina Rachid. - - Piracicaba, 1999.

99 p. : il.

Dissertação (mestrado) - - Escola Superior de Agricultura Luiz de Queiroz, 1999. Bibliografia.

1. Amostragem acidental 2. Amostragem estratificada 3. Arborizaçāo de rua 4. Árvore 5. Inventário 6. Levantamento 7. Paisagismo I. Título

CDD 715.2 


\section{AGRADECIMENTOS}

Ao meu orientador, Hilton Thadeu Zarate do Couto, pela oportunidade de desenvolver este trabalho.

Aos professores Maria Cecilia Mendes Barreto e Benedito Galvão Benze, ambos do Departamento de Estatística da Universidade Federal de São Carlos, pela preciosa orientação e atenção prestadas.

À professora Ana Maria Liner Pereira Lima, do Departamento de Horticultura da ESALQ, pelas importantes dicas fornecidas.

Aos professores Elza de Andrade Oliveira e Valter Roberto Silvério, ambos do Departamento de Ciências Sociais da Universidade Federal de São Carlos, por permitirem o uso do mapa sobre divisão sócio-econômica em São Carlos, fundamental para o desenvolvimento deste trabalho.

Ao professor Antonio Nélson Rodrigues da Silva, da Escola de Engenharia de São Carlos (USP), por ceder o mapa usado para mostrar os quarteirões amostrados neste trabalho.

Aos professores Antonio Natal Gonçalves e João Luís Ferreira Batista, ambos do Departamento de Ciências Florestais da ESALQ, e à professora Maria Cristina Stolf Nogueira, do Departamento de Estatística da ESALQ, pelas opiniões que deram a respeito deste trabalho. 
Aos meus pais, Munir e Marilena, e à minha irmã, Alessandra, pelo apoio e pelo carinho que sempre me dão.

A Munir Rachid e Daniel Wellichan Mancini pelas consultorias de engenheria e de matemática concedidas. 


\section{SUMÁRIO}

Página

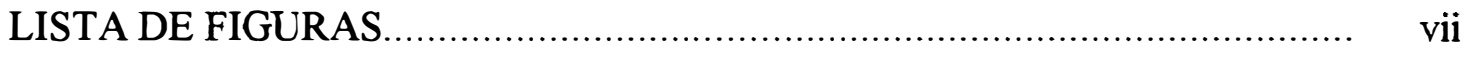

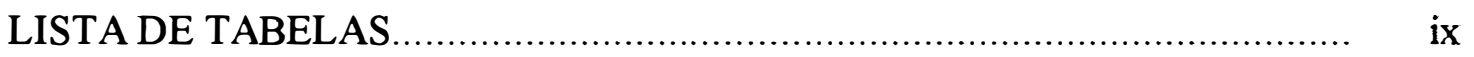

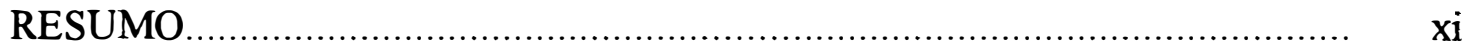

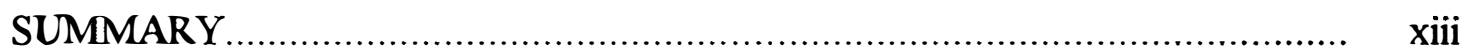

1 INTRODUÇÃO E REVISÃO DE LITERATURA.................................... 15

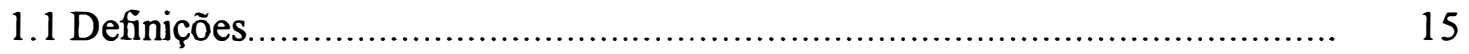

1.2 Considerações sobre os beneficios da arborização................................... 17

1.3 Por que é importante inventariar? .................................................. 19

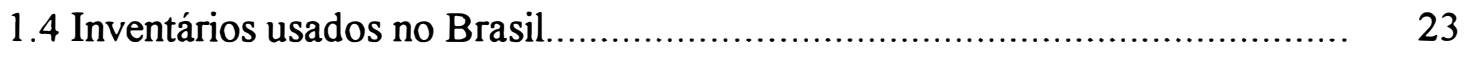

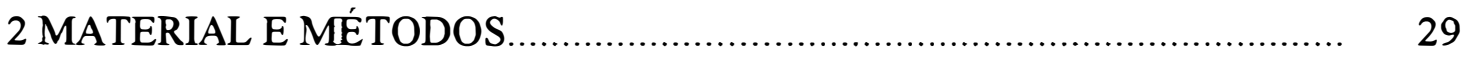

2.1 Caracterização de São Carlos.......................................................... 29

2.2 Área de estudo e unidades amostrais................................................. 30

2.3 Definição das variáveis principais.................................................... 32

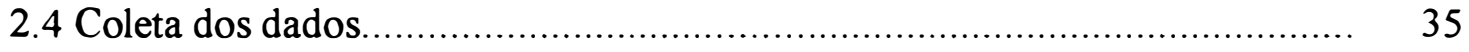

2.5 Plano amostral dos métodos estudados............................................... 40

2.5.1 Amostragem casual simples................................................. 40

2.5.2 Amostragem estratificada....................................................... 42

3 RESULTADOS E DISCUSSÃO ..................................................... 50

3.1 Variável "número de árvores por quilômetro de calçada"........................ 50

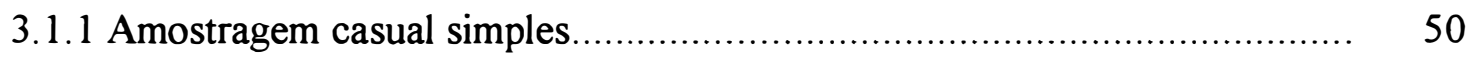

3.1.2 Amostragem estratificada ..................................................... 50

3.2 Variável "número de árvores por hectare" ......................................... 51

3.2.1 Amostragem causal simples............................................... 51

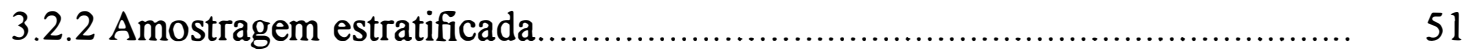

3.3 Análise das variáveis qualitativas para amostragem casual simples.............. 55

3.3. 1 Variáveis comprimento de quadra, largura de rua, tipo de ocupa- 
ção e largura de calçada........................................................... 55

3.3.2 Variável espécie........................................................... 56

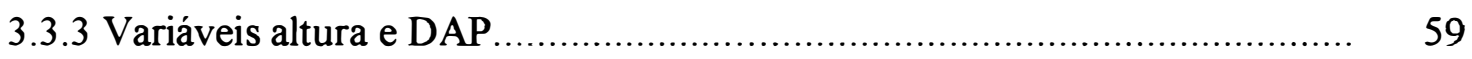

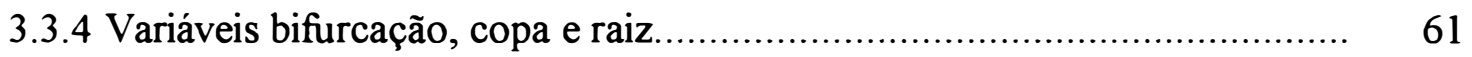

3.3.5 Variáveis porte, área livre, obstáculo, tutor e fio............................... 63

3.3.6 Variáveis muda, frutífera, íntegra, poda, doença, praga, morta e

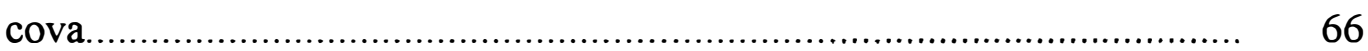

3.4 Análise das variáveis qualitativas para amostragem estratificada................ 70

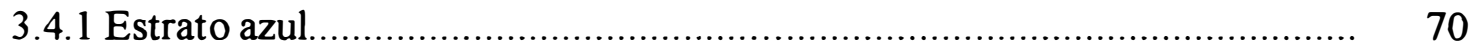

3.4.1.1 Variáveis comprimento de quadra, largura de rua, tipo de ocupação e largura de calçada...................................................... $\quad 70$

3.4.1.2 Variável espécie.......................................................... 70

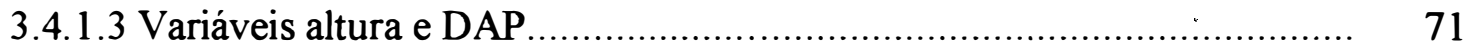

3.4.1.4 Variáveis bifurcação, copa e raiz............................................ 72

3.4.1.5 Variáveis porte, área livre, obstáculo, tutor e fio............................. 72

3.4.1.6 Variáveis muda, frutífera, íntegra, poda, doença, praga, morta e

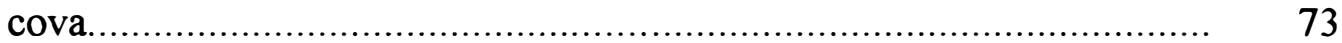

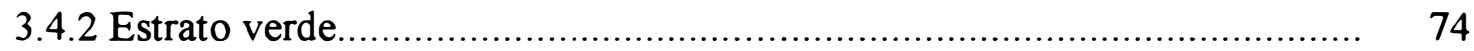

3.4.2.1 Variáveis comprimento de quadra, largura de rua, tipo de ocupação e largura de calçada..................................................... $\quad 74$

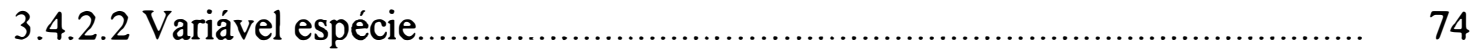

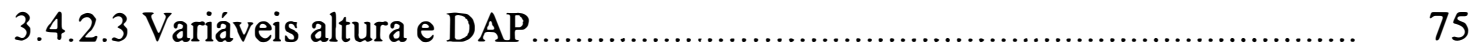

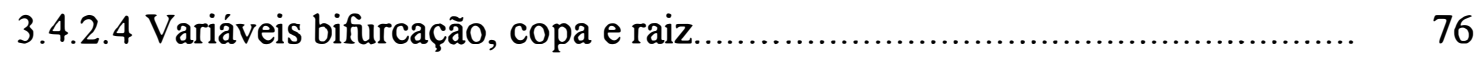

3.4.2.5 Variáveis porte, área livre, obstáculo, tutor e fio............................... 76

3.4.2.6 Variáveis muda, frutífera, íntegra, poda, doença, praga, morta e

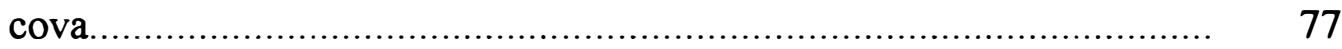

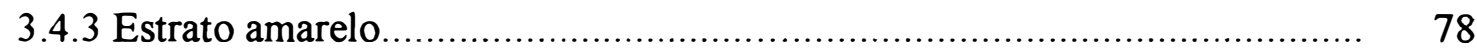

3.4.3.1 Variáveis comprimento de quadra, largura de rua, tipo de ocupação e largura de calçada.. 


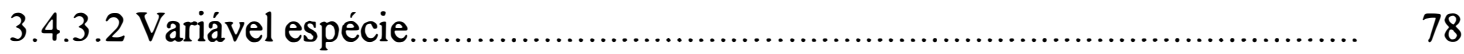

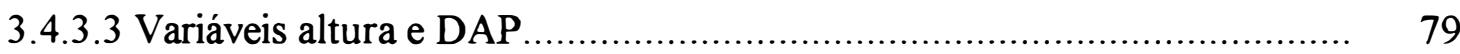

3.4.3.4 Variáveis bifurcação, copa e raiz......................................................... 80

3.4.3.5 Variáveis porte, área livre, obstáculo, tutor e fio................................. $\quad 80$

3.4.3.6 Variáveis muda, frutífera, integra, poda, doença, praga, morta e

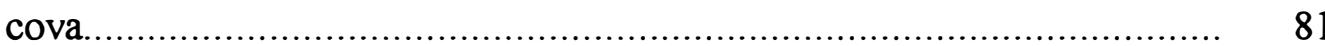

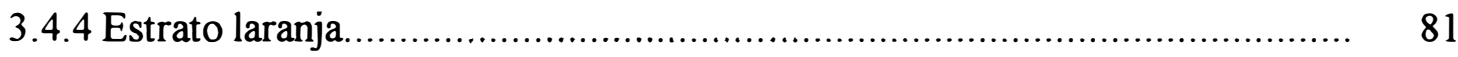

3.4.4.1 Variáveis comprimento de quadra, largura de rua, tipo de ocupação e largura de calçada.................................................................... 81

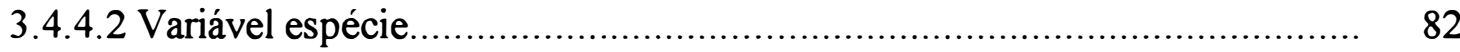

3.4.4.3 Variáveis altura e DAP............................................................... 83

3.4.4.4 Variáveis bifurcação, copa e raiz..................................................... 83

3.4.4.5 Variáveis porte, área livre, obstáculo, tutor e fio.................................. 84

3.4.4.6 Variáveis muda, frutífera, íntegra, poda, doença, praga, morta e

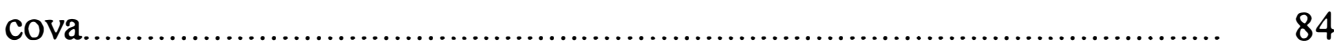

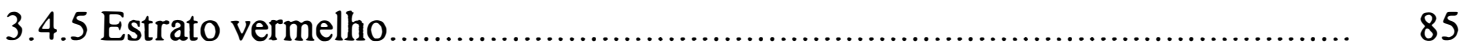

3.4.5.1 Variáveis comprimento de quadra, largura de rua, tipo de ocupação e largura de calçada................................................................... $\quad 85$

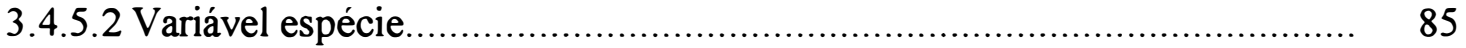

3.4.5.3 Variáveis altura e DAP ............................................................... 86

3.4.5.4 Variáveis bifurcação, copa e raiz....................................................... 87

3.4.5.5 Variáveis porte, área livre, obstáculo, tutor e fio................................. 87

3.4.5.6 Variáveis muda, frutífera, íntegra, poda, doença, praga, morta e

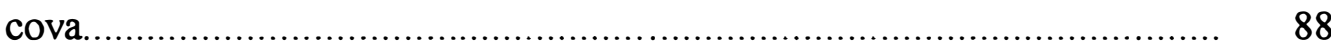

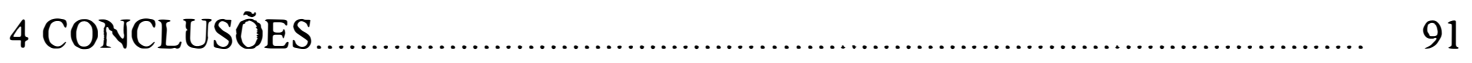

REFERÊNCIAS BIBLIOGRÁFICAS _........................................................ 94 


\section{LISTA DE FIGURAS}

Página

1 Trecho do mapa de São Carlos (SP) contendo os tipos de quarteirões comumente encontrados na área de estudo

2 2a e $2 \mathrm{~b}$ - Trechos do mapa de São Carlos mostrando formatos de quarteirões (números 1 a 4) encontrados em baixa intensidade na área de estudo

3 Trecho do mapa de São Carlos mostrando quarteirões (números 1 e 2) com um dos lados cercado por campo.

4 Representação de um quarteirão com as respectivas dimensões: - comprimento da quadra, B - largura média da calçada, C - metade da largura da rua

6 6a - Trecho do mapa de São Carlos mostrando um quarteirão (número 1) com uma quadra em forma de curva; $6 \mathrm{~b}$ - mesmo trecho do mapa mostrando a adaptação da quadra curva para segmentos de reta.

7 Ficha de coleta de dados

8 Mapa de São Carlos com os quarteirões sorteados na amostragem casual simples 
9 “Mapa da Exclusão em São Carlos” com as cinco categorias (azul, verde, amarelo, laranja e vermelho) correspondentes à porcentagem de chefes de família que ganham acima de 20 salários-mínimos e que neste trabalho figuraram como os cinco estratos.

10 Mapa de São Carlos com os quarteirões sorteados na amostragem estratificada......

11 Porcentagem de quadras para os elementos estudados (plantas vivas, mortas e covas) para cada um dos estratos amostrados 


\section{LISTA DE TABELAS}

Página

1 Resultado da análise estatística obtida com a variável "número de árvores por quilômetro de calçada"

2 Resultado da análise estatística obtida com a variável "número de árvores por hectare"

3 Espécies analisadas na amostragem casual simples com mais de 14 indivíduos: nome científico, nome vulgar, freqüência e porcentagem.

4 Valor médio do diâmetro a altura do peito (DAP) das cinco espécies mais freqüentes levantadas pelo método casual simples, porcentagem de plantas com 4,5 a 8,2 metros de altura, que não atrapalham o trânsito (bifur), com aspecto de copa típico, com raízes que danificam a calçada, com porte adequado ao local do plantio, de plantas que eram mudas, de plantas íntegras, com problema de poda, de doença (doen) e/ou praga

5 Espécies analisadas no estrato azul com mais de 14 indivíduos: nome científico, nome vulgar, freqüência e porcentagem.

6 Espécies analisadas no estrato verde com mais de 14 indivíduos: nome científico, nome vulgar, freqüência e porcentagem

7 Espécies analisadas no estrato amarelo com mais de 14 indivíduos: nome científico, nome vulgar, freqüência e porcentagem 
8 Espécies analisadas no estrato laranja com mais de 14 indivíduos: nome científico, nome vulgar, freqüência e porcentagem.

9 Espécies analisadas no estrato vermelho com mais de 14 indivíduos: nome científico, nome vulgar, freqüência e porcentagem.

10 Porcentagem de plantas da amostragem estratificada que estavam acima de $8,20 \mathrm{~m}$ de altura $(\mathbf{H})$, valor médio do diâmetro a altura do peito (DAP) em centímetros, porcentagem de plantas com copa de aspecto atípico (1) e típico (3), com raizes (raiz) que danificam (1) e não danificam a calçada (3), com porte inadequado (1) e adequado (3) ao local do plantio, com boa área livre ao redor do tronco, que eram mudas (mud), que estavam integras (ínte), que estavam com problema de poda (pod), doença (doe) e/ou praga (pra), de plantas mortas (mort) e de covas sem planta (cov) 


\title{
ESTUDO DA EFICIÊNCIA DE DOIS MÉTODOS \\ DE AMOSTRAGEM DE ÁRVORES DE RUA \\ NA CIDADE DE SÃO CARLOS - SP
}

\author{
Autora: CAROLINA RACHID \\ Orientador: Prof. HIL TON THADEU ZARATE DO COUTO
}

\section{RESUMO}

Este trabalho teve o objetivo de comparar dois métodos de amostragem de árvores de rua a fim de identificar qual o mais eficiente para a cidade de São Carlos. Para isso foi feito o levantamento qualitativo e quantitativo das árvores do sistema viário da área urbana da cidade, empregando-se a amostragem casual simples e a amostragem estratificada por nível sócio-econômico da população. A cidade foi dividida em cinco estratos, identificados por cores, que variaram do azul - com maior porcentagem de chefes de familia ganhando acima de 20 salários-mínimos - ao vermelho - que abrigava a maioria dos bairros mais pobre - passando pelo verde, pelo amarelo e pelo laranja. Para estimar o parâmetro populacional que representa a abundância de árvores foram usadas duas variáveis: o "número de árvores por quilômetro de calçada" e o "número de árvores por hectare". Dos 2.438 quarteirões que compunham a área de estudo, 10\% foram sorteados para constituir a amostra, tanto do método casual simples quanto de cada um dos estratos. De cada unidade amostral selecionada eram anotados o total de quilômetros de calçada, a área por ela ocupada, o número de elementos (plantas vivas, plantas mortas e covas sem planta) existente e suas características. Verificou-se que os dois métodos foram eficientes para fazer o levantamento de árvores de ruas na cidade de São Carlos, mas deu-se preferência à amostragem casual simples, uma vez que o ganho em precisão obtido com a estratificação foi muito pequeno. Entre as duas variáveis principais testadas deu-se preferência ao "número de árvores por quilômetro de calçada", por ser de 
manuseio mais simples. Dos elementos medidos na amostragem casual simples $83,20 \%$ eram plantas vivas, $7,84 \%$ eram plantas mortas e $8,96 \%$ eram covas abertas mas sem árvore. Das plantas vivas, $40,15 \%$ atrapalhavam a passagem de pedestres e/ou veículos, $59,81 \%$ tinham copa com aspecto sadio, $72,65 \%$ tinham raízes que ainda não estavam estragando a calçada, $32,55 \%$ eram inadequadas para o local onde estavam plantadas, apenas $21,91 \%$ tinham boa área livre ao redor do tronco, $47,83 \%$ estavam sob fios, $72,61 \%$ estavam sadias, $23,81 \%$ tiveram problemas de poda, $2,36 \%$ estavam doentes e $2,23 \%$ tinham praga. As cinco espécies mais freqüentes foram Michelia champaca (magnólia amarela), Murraya paniculata (falsa-murta), Schimus molle (aroeira-salsa), Caesalpinia peltophoroides (sibipiruna) e Bauhinia variegata (pata-de-vaca). Michelia champaca e Murraya paniculata também foram as duas espécies mais freqüentes em cada um dos cinco estratos. As principais observações obtidas para cada estrato foram:

- azul - estrato com a maior porcentagem de plantas com problemas de poda $(24,69 \%)$ e com a maior porcentagem de mudas $(9,26 \%)$;

- verde - estrato com a maior porcentagem de plantas acima de 8,20 metros de altura $(6,73 \%)$ e de plantas mortas $(10,82 \%)$;

- amarelo - estrato com a maior média de comprimento de quadras - 121,03 metros - e com a menor largura média de calçada, 2,17 metros;

- laranja - estrato que apresentou a maior porcentagem de quadras ocupadas com escolas $(5,5 \%)$ e a menor porcentagem de plantas frutíferas $(0,89 \%)$;

- vermelho - estrato que possuía a maior porcentagem de plantas adequadas ao local do plantio $(60,88 \%)$ e a menor média de DAP, 10,97 centímetros. 


\section{STUDY OF THE EFFICIENCY OF TWO \\ STREET TREES INVENTORY SYSTEMS \\ IN SÃO CARLOS - SP, BRAZIL}

Author: CAROLINA RACHID

Adviser: Prof. HILTON THADEU ZARATE DO COUTO

\section{SUMMARY}

The purpose of this work is to compare two street trees inventory systems to identify which one will be more efficient to São Carlos. To accomplish that, a survey of the street trees quantity and quality at the urban area of São Carlos was made, using the simple random sampling and the stratified sampling considering the social and economic level of São Carlos population. The city was divided in five strata identified by colors varying from blue - the percentage of the family's head income is over 20 minimum salaries - to red - covering mostly of the poor neigborhoods - using also the green, yellow and orange. To estimate the populational parameters that represent the abundance of the trees, two variables were used: the "number of trees per kilometer of pavement" and the "number of trees per hectare". From the 2438 blocks that compounded the study area, $10 \%$ were randomly selected to constitute the sampling of both: the simple random sampling and each one of the strata. From each sampling unit selected, the total of kilometers of pavement, the area occupied by the block, the number of existing elements (living and dead plants and vacant trees sites) and their characteristics were noted. It was verified that the two methods were efficient to accomplish the survey of the trees at the streets of São Carlos; however, there was a preference for the simple random sampling, since the accuracy level obtained from the stratified sampling was very little. Between the two main tested variables, the preference was given to the "number of trees per kilometer of pavement" for its simple handling. From the elements estimated at the simple random sampling, $83.20 \%$ were living plants, 
$7.84 \%$ were dead plants and $8.96 \%$ were vacant tree sites. From the living plants, $40.15 \%$ were blocking the passage of pedestrians and vehicles, $59.81 \%$ had healthy appearance crowns, $72.65 \%$ had roots which weren't yet damaging the pavement, $32.55 \%$ were inadequate to the areas they were planted, only $21.91 \%$ presented a good area surronding the trunk, $47.83 \%$ were under wires, $72.61 \%$ were healthy, $23.81 \%$ had pruning problems, $2.36 \%$ evidenced diseases and $2.23 \%$ had insect damage. The five most frequent species were Michelia champaca (magnólia amarela), Murraya paniculata (falsa-murta), Schinus molle (aroeira-salsa), Caesalpinia peltophoroides (sibipiruna) and Bauhinia variegata (pata-de-vaca). Michelia champaca and Murraya paniculata also were the two most frequent species in each of the five strata. The main remarks obtained for each stratum were:

- blue - stratum presenting the highest percentage of plants with pruning problems (24.69\%) and the highest percentage of seedling $(9.26 \%)$;

- green - stratum presenting the highest percentage of plants over 8.20 meters of height $(6.73 \%)$ and the highest percentage of dead plants $(10.82 \%)$;

- yellow - stratum presenting the largest average quarters length - 121.03 meters - and the smallest average pavement width, 2.17 meters;

- orange - stratum presenting the highest percentage of quarters filled by schools $(5.5 \%)$ and the lowest percentage of fruitful plants $(0.89 \%)$;

- red - stratum presenting the highest percentage of plants adequated to the planting areas $(60.88 \%)$ and the lowest average of $\mathrm{DBH}, 10.97$ centimeters. 


\section{INTRODUÇ̃̃O E REVISÃO DA LITERATURA}

\subsection{Definições}

Vários trabalhos e estudos científicos têm sido feitos nas últimas duas décadas sobre o tema "arborização urbana", seja descrevendo os beneficios advindos da presença de vegetação no meio urbano, seja mostrando técnicas de quantificação de áreas verdes, seja sugerindo espécies mais apropriadas para locais com algum tipo de restrição ou mesmo indicando metodologias de amostragem de árvores de ruas.

Atualmente muitos países estão preocupados em promover ações combinadas de proteção do meio ambiente com desenvolvimento, objetivando alcançar a melhoria da qualidade de vida da população. Essas ações, segundo Philippi Jr. \& Pelicioni (1998), estão descritas em um documento - Agenda 21 - resultante do compromisso firmado no Rio de Janeiro, em 1992, por 170 países. Um dos grandes temas da Agenda 21 é a administração das áreas habitadas e prega que "a qualidade de vida humana depende em grande parte das condições fisicas, sociais e econômicas dos locais onde a população vive, suas comunidades, vilas ou cidades".

Para uma cidade se tornar habitável e confortável é necessário que nela existam instalações e serviços, definidos por Ávila (1978) como equipamentos urbanos, que são: luz elétrica, água encanada, esgotos, escolas, moradias, ruas, bosques, praças e parques, hospitais, fábricas, bombeiros, clubes, museus, correios e demais fatores da vida urbana.

Lombardo (1990) relata que "na expansão acentuada dos ambientes construídos pela sociedade não se evidenciou qualquer preocupação com a qualidade de vida dos habitantes, o que significa dizer que a questão ambiental, como tantas outras, foi 
negligenciada". A autora ressalta o importante papel que a vegetação desempenha nas áreas urbanas no que se refere à qualidade ambiental e afirma que através da vegetação pode-se avaliar a qualidade de vida urbana."

Kuchelmeister \& Braatz (1993) compartilham da mesma opinião ao afirmarem que árvores e florestas no meio urbano representam um papel importante na melhoria da qualidade de vida das cidades.

A ciência referente ao cultivo de árvores florestais denomina-se Silvicultura. Uma ramificação desta ciência é a Silvicultura Urbana, que tem como objetivo (id. ibid., p.5) o cultivo e manejo de árvores para contribuirem ao bem-estar fisiológico, sociológico e econômico da sociedade urbana.

Outro termo que pode ser usado para representar o cultivo de árvores no meio urbano é o verde urbano, considerado por Malinsky (1985) como um sistema que poderia contribuir de forma decisiva na melhoria das condições de vida de nossas cidades. Para ele, o sistema poderia ser desenvolvido a partir do elemento unitário, a árvore, e ir crescendo em complexidade para formar a arborização da rua, a arborização do bairro ou zona, o conjunto das áreas verdes da cidade etc.

Mais habitual é encontrar a denominação arborização urbana. P Para Kirchner et al. (1990), a arborização urbana abrange três setores: áreas verdes públicas, áreas verdes privadas e arborização de ruas, sendo a arborização de ruas por eles considerada como a rede de união entre as áreas verdes urbanas, estas constituídas por praças, parques e jardins.

Também Mello Filho (1985) descreve as modalidades de arborização que a estrutura urbana comporta: arborização viária, arborização de parques e jardins, arborização de áreas privadas (em quintais de residências, hotéis, hospitais, clubes cemitérios etc.) e arborização nativa residual dentro da malha urbana.

Milano (1990) admite que seja possível dividir a arborização urbana basicamente em pública e privada, sendo a arborização pública, por sua vez, dividida em dois sub-setores específicos que são o das áreas verdes e o da arborização de ruas. Para 
ele, áreas verdes e ruas arborizadas são espaços distintos, porém inter-relacionados no contexto da arborização urbana.

Árvore de rua é definida por Miller (1988) como a árvore pertencente ao poder público, crescendo em vias públicas, geralmente entre a calçada e o meio-fio.

\subsection{Considerações sobre os benefícios da arborização}

As funções desempenhadas pela arborização urbana no metabolismo da cidade são relacionadas por Mello Filho (1985) como sendo as descritas abaixo:

* função química - absorvendo gás carbônico e exalando oxigênio, as árvores melhoram a qualidade do ar urbano;

* função fisica - a copa das árvores oferece sombra, absorve ruídos e dá proteção térmica;

* função paisagistica - as árvores transferem valores resultantes de sua textura foliar e de suas mudanças estacionais aos habitantes da cidade;

* função ecológica - a árvore oferece abrigo e alimentação aos animais, especialmente aves de pequeno porte;

* funcão psicológica - as massas verdes oferecem uma presença calmante aos citadinos estressados.

Também Kuchelmeister \& Braatz (1993) citam vários beneficios advindos da presença de árvores e de áreas verdes no meio urbano, entre eles o de ajudar no resfriamento das cidades, funcionar como filtros naturais, absorver barulho, proteger e melhorar a qualidade dos recursos naturais, incluindo solo, água, flora e fauna.

Para Lombardo (1990) a arborização ajuda a caracterizar a paisagem das ruas, praças e parques, contribuindo para dar noção de espaço ao ser humano, além de realçar o ambiente fisico da cidade.

Nowak (1994) acredita que as árvores de ruas sejam um componente menos significativo da arborização urbana como um todo, pois seus beneficios, quando 
considerados exclusivamente, tais como redução da temperatura e da poluição do ar são criticáveis.

Quanto ao aspecto diminuição de ruídos, Reethof \& Heisler (1976) opinam que para alcançar este efeito é necessário haver uma barreira de árvores densa e extensa e não somente árvores isoladas.

Em relação ao controle microclimático em áreas urbanas, provavelmente o beneficio mais importante das árvores seja, segundo Heisler \& Herrington (1976), o controle da radiação, principalmente a radiação solar: "Uma superficie sombreada irradia menos calor para as pessoas".

Ryan (1976) compartilha da mesma idéia ao afirmar que um dos mais proveitosos atributos de uma árvore é a sombra que ela proporciona no verão.

Dember (1993) mostra em seu artigo uma cidade da China, Beijing, onde árvores são plantadas no centro da cidade com a finalidade de fornecer sombra aos comerciantes de rua.

McPherson (1993) relata que a presença de uma única árvore de copa larga cobrindo o lado oeste de uma casa de tijolos foi capaz de proporcionar uma economia de energia com uso de ar-condicionado no horário de pico (17 horas) de 19\%, conforme estudo realizado por empresa de e nergia em Chicago (Estados Unidos).

As árvores de rua funcionam como corredor que interliga as várias modalidades de áreas verdes, ou seja, as praças, os parques, as áreas livres, os jardins de áreas particulares, permitindo a circulação de pássaros e insetos, que têm importante atuação na dispersão do pólen das flores.

É o que mostra Milano (1990) ao afirmar que a arborização de ruas tem função importante na formação de uma malha no tecido urbano correspondente ao sistema viário, constituindo fator de homogeneização e integração da cobertura vegetal nas cidades.

Milano (1990), Kuchelmeister \& Braatz (1993) e Nowak (1994) enfatizam que as árvores de ruas desempenham um papel importante em áreas mais densamente 
ocupadas da cidade, local em geral limitado para a implantação de parques e praças. Portanto, nesses locais a ênfase deve ser dada às árvores de rua.

Basset (1978) nota que somando gramados, jardins, árvores de rua, parques e espaços verdes não explorados obtêm-se uma extensa área verde dentro e ao redor de áreas urbanas. Todavia, muitos moradores não reconhecem o silêncio e os papéis imutáveis que as árvores e outras plantas exercem na melhoria da qualidade dos seus ambientes.

Por ser dificil quantificar todos os beneficios advindos da arborização urbana torna-se problemático convencer as autoridades municipais sobre sua importância (Gray et al., 1993).

Para Kuchelmeister \& Braatz (1993) a arborização deveria fazer parte dos serviços essenciais de uma cidade, porém na maioria dos países a arborização urbana é vista como uma atividade esteticamente desejada mas não necessariamente prioritária.

\subsection{Por que é importante inventariar?}

É reconhecida a importância de quantificar a cobertura verde de uma cidade, pois aí está refletido um indicador da qualidade de vida daquele ambiente urbano. Mesmo não fazendo parte dessa quantificação, as árvores de ruas começam a ser requisitadas para expressar esse índice.

Oliveira (1996) prega a necessidade de estabelecer valores mínimos de Índice de Área Verde (IAV) e Porcentagem de Área Verde (PAV) ou qualquer outro indicador associado à qualidade ambiental ou de vida, mesmo que seja por métodos indiretos ou aproximações. O autor encontrou para a cidade de São Carlos um IAV médio igual a $2,65 \mathrm{~m}^{2} /$ habitante, sendo que o recomendável seria entre 12 e 13 $\mathrm{m}^{2} /$ habitante, e uma PAV média igual a $2,46 \%$.

Milano (1990) acredita que a contribuição das ruas arborizadas para a quantidade total de área verde da cidade seja algo significativo: a cidade de Maringá, por exemplo, possui $20,6 \mathrm{~m}^{2}$ de área verde pública por habitante, sendo $32,4 \%$ deste valor 
advindo de praças e parques e $67,6 \%$ das árvores de ruas, estimado a partir de dados de diâmetro médio e distribuição diamétrica das espécies mais freqüentes.

Segundo Profous \& Rowntree (1993) 10\% da área metropolitana de Praga (República Tcheca) era coberta, em 1993, com vegetação florestal, incluindo árvores de ruas, de parques, de áreas privadas e de quintais.

As árvores de ruas correspondem a uma entre cada dez árvores de Chicago, 1 em cada 37 no subúrbio de Cook e 1 em cada 77 em DuPage, nos Estados Unidos (Nowak, 1994).

Segundo Basset (1978), inventários são parte integral do sistema de manutenção de árvores de ruas. Apesar de considerar as árvores de ruas como uma pequena fração da vegetação de áreas urbanas, faixas plantadas ao longo de ruas nos Estados Unidos são estimadas em 100 milhões de árvores, cobrindo 60.000 ha, com espaçamento de 12 metros entre elas.

Dembner (1993) adaptou um artigo sobre floresta urbana no qual mostra que $40 \%$ de todas as cidades da China tinham mais de $30 \%$ de cobertura vegetal e especificamente na cidade de Beijing quantificou-se, em 1982, $64.000 \mathrm{~km}$ de calçadas cobertas com árvores distantes umas das outras de 3 a 4 metros. Este valor corresponderia a um total entre 16.000 e 21.333 árvores de ruas.

Para Miller (1988), a administração de um recurso começa com o inventário desse recurso, e arborização urbana não é exceção.

Escrevendo sobre Silvicultura Urbana, Kuchelmeister \& Braatz (1993) citam que entre os elementos técnicos do processo de planejamento da arborização urbana estão o inventário, seleção das espécies e plantio, manutenção, poda e/ou remoção de árvores.

No Brasil, as cidades arborizadas não contam com um planejamento prévio e nem com a adequada manutenção. Considerada a arborização como um todo, este é um problema que se faz sentir mais significativamente na arborização de ruas. Correções para problemas dessa natureza requerem sempre um adequado diagnóstico 
prévio da situação, o que é realizado através de inventários específicos (Milano \& Soares, 1990).

Para Santos et al. (1991), somente por meio do conhecimento de uma situação pode-se fundamentar opiniões, traçar planos e mesmo replanejar a arborização de uma cidade, daí a importância da análise dos indivíduos vegetais através de um levantamento.

Através de um inventário chega-se ao conhecimento pleno da situação da arborização, que para Milano et al. (1992), é fator básico para seu adequado manejo e também para seu replanejamento.

Nowak (1994) acredita que por meio de amostragens e inventários seja possível obter informações estruturais a respeito da arborização urbana, como por exemplo, quantidade, localização, tamanho e condição das árvores de ruas ou de parques, que auxiliarão no manejo da arborização.

Profous \& Rowntree (1993) mostram um exemplo de como o inventário auxiliou no manejo da arborização das áreas públicas de Praga (República Tcheca): das cinco espécies mais plantadas, que representavam $65 \%$ do total de espécies de árvores, uma delas - Tilia spp.- estava sendo evitada no novos plantios por ser muito sensível ao sal usado durante o inverno.

O tipo de inventário vai depender, na opinião de Miller (1988), do tamanho da comunidade, do nível de serviço desejado e dos potenciais problemas com a vegetação. $\mathrm{O}$ mais eficiente é aquele adaptado às necessidades da comunidade. Para o autor, assim que as informações descritivas sobre a população de árvores for adequada para atingir os objetivos administrativos, o método para obter essas informações não deve ser alterado.

Os inventários para avaliação da arborização de ruas podem ser por amostragem ou totais, esses últimos só justificados para análise quantitativa da arborização ou em análise também qualitativa de cidades pequenas (Nunes, 1992). 
Segundo Milano (1994), inventários totais da arborização de ruas em geral são inviáveis dados o tempo e recursos necessários para sua realização. Portanto, usualmente adotam-se inventários por amostragem.

Para Miller (1988) a seleção ou delineamento de um sistema de inventário deve ser entendida com o objetivo global de prover informações essenciais aos administradores nas suas tomadas de decisão, num tempo adequado e com custo razoável.

Admitindo-se que indices quantitativos isoladamente normalmente expressam pouco da realidade da arborização urbana e que caracterizações qualitativas amplas são muitas vezes duvidosas pela dificuldade de obtê-las, somente avaliações e análises combinadas (quali-quantitativas) possibilitam considerações efetivamente úteis (Milano et al., 1992).

O inventário não precisa ser complexo ou com muitos parâmetros de medição, mas deve conter, segundo Miller (1988), um mínimo de informação que permita ao administrador tomar decisões inteligentes. A finalidade da amostragem é fornecer estimativas de parâmetros num custo razoável e exato o suficiente para atender aos objetivos da administração; por isso é preferivel usar amostragem para população cujo custo para inventariar $100 \%$ é proibitivo.

O nivel de precisão e o detalhamento da avaliação, na opinião de Nunes (1992) estão diretamente relacionados com a situação existente em termos de recursos financeiros, pessoal, porte da cidade e finalidade da mesmá.

Para Basset (1978) o sucesso de um sistema de inventário consiste em quatro aspectos: 1) os dados coletados devem ser pertinentes, 2) deve haver treinamento e supervisão adequados do pessoal de campo para assegurar uma informação correta, 3) os dados devem ser atualizados periodicamente, 4) o sistema deve ser planejado para facilitar a rápida recuperação e manipulação dos dados, de maneira econômica e compreensível.

$\mathrm{O}$ autor (id. ibid., p.633) considera como informações pertinentes aquelas que descrevem as características e condições das árvores bem como do lugar onde elas 
estão crescendo. Cita como características importantes as seguintes: data, características e condições do local de plantio (tamanho da cova, altura da fiação, intensidade de tráfego de veículos), características da árvore (espécie, diâmetro e altura, dimensões da copa, altura do primeiro galho, idade, época de plantio e outros), condições da árvore (vigor, quantidade de galhos mortos, injúrias, doenças, pragas), recomendações quanto aos aspectos remoção, plantio e poda, necessidades do plantio (textura e profundidade do solo, vigor das árvores vizinhas, remoção de toco etc).

Dificilmente trabalhos de amostragem incluem a cova na quantificação das árvores, mas Miller (1988) frisa que quando uma cova vazia é encontrada, ela deve ser identificada como um lugar potencial para futuro plantio de uma árvore.

Para Miller (ibid.) é importante distingüir informação transitória de informação de natureza mais permanente, por exemplo: identificar as espécies de árvores é uma informação mais durável que descrever as necessidades de poda de uma árvore em particular; estragos na calçada é uma informação transitória, portanto, deveria ser

correlacionada com as espécies para ver quais estão causando mais problemas de manutenção.

Outro emprego importante de um inventário é, na opinião de Basset (1978), o de previnir prejuízos causados pelas árvores, conforme mostra o seguinte exemplo dado pelo autor: verificou-se em um município dos Estados Unidos que as três espécies mais plantadas nas ruas eram a macieira silvestre, o freixo e o plátano. Muitas macieiras apresentavam sintomas de declínio causado por uma doença que acometia as folhas, e por serem em grande número, poderiam infestar outras árvores; então, as ruas que possuíam mais de cinco árvores da mesma espécie eram pulverizadas. Isso só foi conseguido por meio de inventário, que permitiu que houvesse um planejamento.

\subsection{Inventários usados no Brasil}

Nunes (1992) estabelece duas modalidades básicas de arborização urbana 
como objeto de avaliação, que são as áreas verdes públicas ou privadas e a arborização de ruas.

Alguns autores fizeram levantamento quali-quantitativo da arborização de ruas de uma determinada região da cidade, como por exemplo, Costa \& Kaminski (1990) num Conjunto Habitacional de Foz do Iguaçu (PR), Santos \& Teixeira (1990) no centro de Santa Maria (RS), Sousa et al. (1990) no centro de Botucatu (SP), Santos et al (1991) na região central de Bento Gonçalves (RS), Lima (1993) no centro de Piracicaba (SP), ou mesmo na cidade toda como foi o caso de Toledo Filho \& Parente (1985) em Moji Mirim (SP) e Martins et al. (1992) em Viçosa (MG).

Milano (1994) escreve que os processos de amostragem são aplicáveis tanto para avaliações quantitativas como para avaliações qualitativas, mas que o nível de precisão das variáveis, quando forem várias as características a avaliar, estará vinculado às características da variável principal previamente definida.

Couto (1994) cita como variável de grande importância o "número de árvores por quilômetro de rua ou calçada" ou o "número de árvores por hectare" e considera corretas as informações fornecidas tanto por comprimento de calçada quanto por comprimento de rua, mas acredita que para efeito de comparação seria importante a padronização.

A maioria dos trabalhos de inventários de árvores de ruas realizados no Brasil utilizam como variável principal o número de árvores por quilômetro de calçada, conforme será visto a seguir. Também serão mostradas as metodologias de amostragem empregadas, as unidades de amostragem adotadas, entre outros aspectos.

Milano (1987) usou amostragem casual simples para fazer o levantamento quali-quantitativo das árvores de ruas da cidade de Curitiba. Com base no mapa da cidade, subdividido em quadrículas de $1 \mathrm{~km}^{2}$, adotou como unidade amostral e potencial as quadrículas de $500 \times 500$ metros que possuíam pelo menos $50 \%$ da quilometragem total de ruas arborizadas. Para homogeneizar as diferentes densidades de rua por região da cidade, o autor considerou como variável principal o número de árvores por quilômetro de calçada arborizada. De um total de 271 unidades de amostragem 
potenciais, foram sorteadas 15 para a amostragem, número que deu consistência para fornecer as informações desejadas para um nível de $95 \%$ de probabilidade e limite de erro de $15 \%$.

Biondi (1985) empregou o sistema de amostragem casual simples para inventariar as árvores de ruas da cidade do Recife (PE). Pelo mapa oficial, a autora determinou as ruas que eram arborizadas, conforme o levantamento florístico da cidade. Utilizando como unidades de amostragem retângulos de 350 × 560 metros de dimensões, a autora encontrou uma população potencial composta por 220 unidades de amostragem; das unidades sorteadas só foram inventariadas as quadras que tinham pelo menos uma árvore para cada 30 metros.

A fim de fazer a avaliação quantitativa das árvores de ruas de Petrolina (PE), Lima et al. (1990) obtiveram as unidades de amostragem dividindo a cidade em parcelas de 250 × 250 metros, nas quais fizeram o inventário total da arborização de ruas. Das ruas efetivamente arborizadas, os autores sortearam uma amostra para fazer a avaliação qualitativa das árvores, em parcelas de 250 metros de calçada. Foram necessárias 60 unidades amostrais para satisfazer a condição de $95 \%$ de probabilidade e $10 \%$ de erro na estimação do número médio de árvores por parcela.

O diagnóstico da arborização de ruas de Apucarana (PR) foi feito por Nunes (1992) empregando amostragem casual simples; para isso, a cidade foi dividida em unidades de amostragem de 250 × 500 metros e só foram incluídas aquelas que continham $50 \%$ ou mais do total de quilometragem das suas ruas arborizadas. As unidades foram sendo sorteadas uma a uma até atingir a intensidade amostral de $5 \%$, com probabilidade de $95 \%$ e limite de erro de $10 \%$, para estimar o número de árvores por quilômetro de calçada arborizada.

Todos os trabalhos até agora exemplificados utilizaram unidades amostrais de tamanho fixo e restringiram aquelas unidades que possuíam baixa freqüência de arborização. A informação sobre freqüência ou distribuição da arborização é geralmente fornecida por um órgão da administração municipal que tem a catalogação das árvores, 
mas são poucas as cidades que dispõem dessa informação no momento em que se está preparando a amostragem.

Segundo Miller (1988), a maioria das cidades de tamanho médio dos Estados Unidos subdivide a população de árvores nas menores unidades, como por exemplo, em distrito, vizinhança ou quarteirão.

Milano et al. (1992) deram preferência às unidades amostrais menores depois de realizarem o trabalho citado abaixo.

Os autores compararam a eficiência do tamanho e forma de unidades de amostragem no inventário quali-quantitativo da arborização de Curitiba: no ano de 1984 usaram unidades com 500×500m e em 1991 subdividiram-nas em duas unidades retangulares, de $250 \times 500 \mathrm{~m}$. Nos dois casos os autores consideraram apenas as unidades que apresentavam arborização em $50 \%$ ou mais da longitude total de suas ruas, tendo no total 335 unidades amostrais para o primeiro inventário e 667 para o segundo. Usando como variável principal o número de árvores por quilômetro de calçada arborizada, foram amostradas 15 unidades em 1984 e 24 unidades em 1991, mas que em termos relativos correspondeu a uma intensidade amostral de 4,47\% para o primeiro caso e de 3,59\% para o segundo. Com isso, os autores concluíram que a unidade de amostragem retangular teve vantagem em relação à de $500 \times 500 \mathrm{~m}$, na medida em que diminuiu a necessidade de área efetiva amostrada, economizando tempo e recursos financeiros no levantamento de informações. Concluíram também, que o uso de maior número de amostras, para um mesmo local, aumentou a possibilidade de uma melhor distribuição aleatória das unidades sorteadas, resultando num inventário que retratou melhor a arborização das ruas de Curitiba.

Malavasi et al. (1995) fizeram um inventário da arborização do centro de Itaguaí (RJ) utilizando amostragem casual simples englobando 30 unidades amostrais. Os autores também adotaram unidades de amostragem pequenas, neste caso a unidade de amostragem escolhida foi a quadra, e inventariaram a vegetação arbórea situada em ambas as calçadas e/ou passeios. 
. No presente trabalho serão estudadas duas metodologias de amostragem de árvores de ruas - amostragem casual simples e amostragem estratificada -a fim de verificar qual é a mais eficiente para o levantamento da arborização viária da cidade de São Carlos. Em ambos os métodos serão usadas como unidades amostrais os quarteirões que compõem a cidade, independentemente da dimensão que possuam $\mathrm{e}$ independentemente do índice de arborização que apresentem. As variáveis principais a serem analisadas nas duas metodologias serão o número de árvores por quilômetro de calçada e o número de árvores por hectare, com o objetivo de verificar a aplicabilidade das mesmas. .

Usa-se a estratificação em trabalho de amostragem para aumentar a precisão nas estimativas das características da totalidade da população (Cochran, 1977), mediante a escolha de uma variável que tenha relação com a característica principal que se queira medir nessa população.

Para fazer o inventário qualitativo e quantitativo da arborização das ruas de Belém (PA), Brasil \& Barros (1994) estratificaram a cidade em função do relevo, pois este confere à cidade características facilmente distingüíveis em baixada $(60 \%$ do território está abaixo do nível do mar) e terra firme. Para o inventário quantitatito foi empregado o processo de amostragem casual por transectos (ruas e avenidas), uma vez que o traçado urbano era muito desuniforme, não permitindo delimitar as unidades de amostragem em tamanhos regulares. $O$ inventário qualitativo foi obtido em sub-amostras de 100 metros cada dispostas sistematicamente nos transectos; o número total de amostras analisadas foi 34. Para testar a eficiência da estratificação comparou-se as médias da variável número de árvores por quilômetro existente em cada transecto por meio do "teste t" a 95\% de probabilidade e os autores concluíram pela conveniência da estratificação. Mas verificaram que a divisão em apenas dois estratos não foi suficiente para diminuir a variação das observações dentro de cada um deles, pois os limites de erro encontrados foram muito altos $(63,24 \%$ e $34,88 \%)$. Para maior precisão, seria necessário sub-estratificar a área de estudo a partir da identificação de outros fatores que contribuem para a variabilidade na distribuição das árvores de Belém. 
Os métodos de amostragem propostos neste trabalho constituem um meio econômico de diagnosticar a arborização viária de uma cidade, uma vez que não dependem de tecnologia avançada, podem ser aplicados por uma equipe de poucas pessoas e os equipamentos requeridos são baratos e de fácil aquisição.

É importante apresentar a metodologia de medição e análise para outros administradores ambientais para dar-lhes a opção de usar essa metodologia imediatamente, sem ter que perder tempo pesquisando várias possibilidades (Gray et al., 1993). 


\section{MATERIAL E MÉTODOS}

\subsection{Caracterização de São Carlos}

O município de São Carlos localiza-se a $22^{\circ} 01$ '22' de Latitude Sul e 47 53'38' de Longitude Oeste; tem uma área de 1.120 km² $^{2}$ e está no centro do Estado de São Paulo, a $230 \mathrm{~km}$ da capital. É formado pela sede de São Carlos mais os distritos de Vila Nery, Bela Vista Sãocarlense, Santa Eudóxia e Água Vermelha, sendo que estes dois últimos ficam distantes da sede.

Destacando-se no setor agropecuário, o município é sobretudo um importante pólo industrial do interior, com cerca de 600 indústrias, algumas de grande porte, além de abrigar hoje um dos mais importantes parques de alta tecnologia do país, com mais de 50 empresas fornecedoras de serviços e produtos de tecnologia avançada.

É reconhecido como um dos maiores centros de ensino superior do país, fora das capitais, com duas universidades públicas e outras duas instituições de ensino superior mantidas pela iniciativa privada.

Conta com uma população de 175.517 habitantes, sendo 164.103 da área urbana, segundo o último censo do IBGE, de 1996.

Pelo sistema de classificação climática de Köppen, São Carlos está entre os tipos Cwa.i (clima tropical com verão úmido e inverno seco) e Aw.i (clima quente com inverno seco). A pluviosidade está limitada entre 1.500 e $1.700 \mathrm{~mm} / \mathrm{ano}$; as temperaturas médias dos meses mais quentes e mais frios são, respectivamente, $23,1^{\circ} \mathrm{C}$ e $18,1^{\circ} \mathrm{C}$ (Lorandi, 1985).

Os solos da região (id. ibid., p.165) são predominantemente do tipo Latossolo Vermelho-Amarelo; atualmente a vegetação que predomina é a de cerrado, 
sendo caracterizada por uma formação não-florestal herbáceo-lenhosa e herbáceoarbustiva, com árvores perenifólias.

\section{2 Área de estudo e unidades de amostragem}

O trabalho abrangeu a cidade de São Carlos mais os distritos Vila Nery e Bela Vista Sãocarlense, constituindo a área onde foram aplicados os dois métodos de amostragem de árvores de ruas, casual simples e estratificada. Não fizeram parte desse estudo as áreas do município destinadas exclusivamente para fins industriais.

O sistema de referência utilizado neste trabalho foi o mapa oficial da cidade de São Carlos na escala 1:10.000 do ano de 1995 (também estão contidos no mapa os dois distritos, Vila Nery e Bela Vista Sãocarlense). Por meio dele foi possível a identificação das 2.438 unidades de amostragem que compuseram a população. A unidade de amostragem adotada neste trabalho foi o quarteirão, a seguir definido.

A unidade de amostragem predominantemente encontrada na área de estudo foi o quarteirão composto por quatro lados - cada lado denominado quadra conforme pode ver visto na figura 1 .

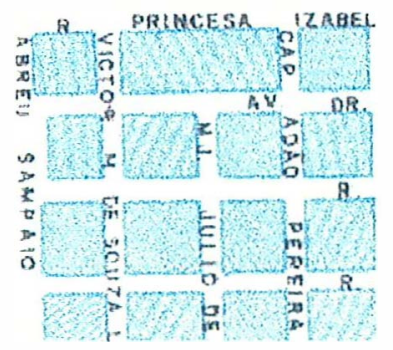

Figura 1 - Trecho do mapa de São Carlos (SP) contendo os tipos de quarteirões comumente encontrados na área de estudo.

Outros formatos de quarteirões também foram encontrados, conforme indicam os números de 1 a 4 da figura 2 . 


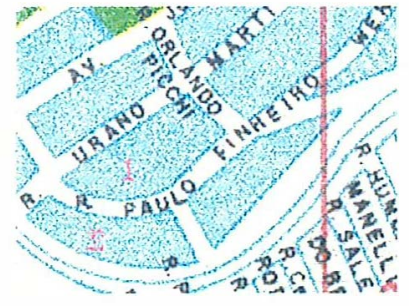

$2 \mathrm{a}$

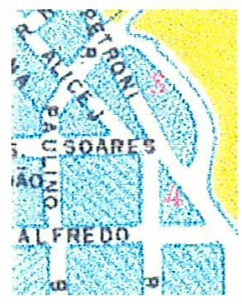

$2 b$

Figura 2 - 2a e 2b- Trechos do mapa de São Carlos mostrando formatos de quarteirões (números 1 a 4) encontrados em baixa intensidade na área de estudo.

Alguns quarteirões não eram cercados por rua em um dos seus lados, mas apresentavam um limite bem definido, como por exemplo linha de trem, um rio, um trecho de mata; também estes, foram considerados como unidades de amostragem. A figura 3 mostra exemplos de quarteirões (identificados pelos números 1 e 2) que têm um dos lados cercado por uma área de campo.

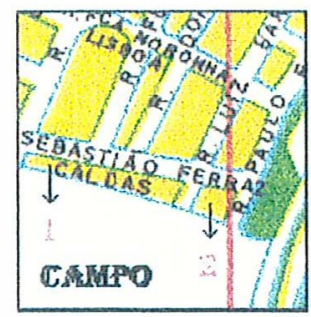

Figura 3 - Trecho do mapa de São Carlos mostrando quarteirões (números 1 e 2) com um dos lados cercado por campo.

Foram numerados todos os quarteirões do perímetro urbano nos quais existiam residências, indústrias, comércio, clubes, igrejas, hospitais, repartições públicas etc e também aqueles nos quais não havia ocupação ou infra-estrutura (como por 
exemplo meio-fio e calçamento), desde que presentes no mapa, por ocasião do levantamento do sistema de referência.

Tendo-se determinado o total de unidades de amostragem na população, procedeu-se ao sorteio de uma amostra. Esta amostra foi composta por um número de quarteirões dos quais se extraíam as informações necessárias para compor as variáveis analisadas neste trabalho.

\subsection{Definição das variáveis principais}

As principais variáveis estudadas neste trabalho foram aquelas que representam a abundância de árvores, expressas em "número de árvores por quilômetro de calçada" e "número de árvores por hectare".

A variável "número de árvores por quilômetro de calçada" foi definida como a razão entre duas características populacionais: número total de árvores existentes nas calçadas e o total de quilômetros de calçadas na área de estudo. De maneira análoga, definiu-se a variável "número de árvores por hectare" como a razão entre o total de árvores existentes nos quarteirões e a área total ocupada por estes quarteirões no local de estudo.

Para a determinação destas duas variáveis principais era imprescindivel a medição do comprimento das quadras, da largura da calçada de cada uma das quadras, assim como da metade da largura da rua que delimitava cada uma das quadras. $\mathrm{O}$ comprimento das quadras foi obtido pela medição no mapa de escala 1:10.000 e a medição da largura das calçadas e das ruas foi feita no local, por meio de uma trena. Quando a calçada de uma mesma quadra possuía diferentes larguras, eram tomadas três medidas e o valor final correspondia à média destas medidas.

Na figura 4 há o exemplo das dimensões de um quarteirão citadas acima; vê-se que o desenho com traço preto corresponde ao quarteirão, o traço em cinza representa o quarteirão contornado pelas calçadas e o tracejado em laranja, o meio da rua. 


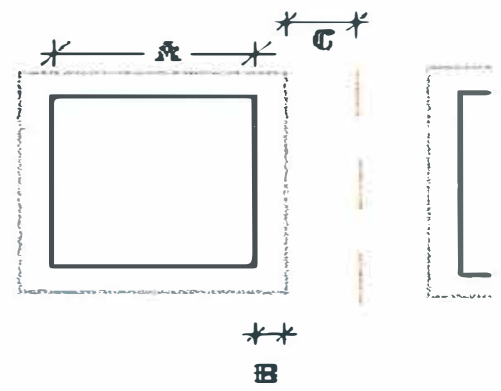

Figura 4 - Representação de um quarteirão com as respectivas dimensões: comprimento da quadra, $\mathbf{B}$ - largura média da calçada, $\mathbb{C}$ - metade da largura da rua.

Pelo critério adotado, o total de quilômetros de calçada de um quarteirão foi estimado somando-se aos comprimentos de cada uma das suas quadras as larguras das calçadas, de maneira a obter-se o perímetro representado na figura 4 pela cor cinza (retângulo maior).

A área total pertencente a um quarteirão foi estimada como sendo aquela área ao redor do quarteirão que se estendia até o meio da rua que circundava cada uma das quadras. Aproveitando o desenho da figura 4, vê-se que esta área total ao redor do quarteirão corresponde à área marcada com cor azul na figura 5.

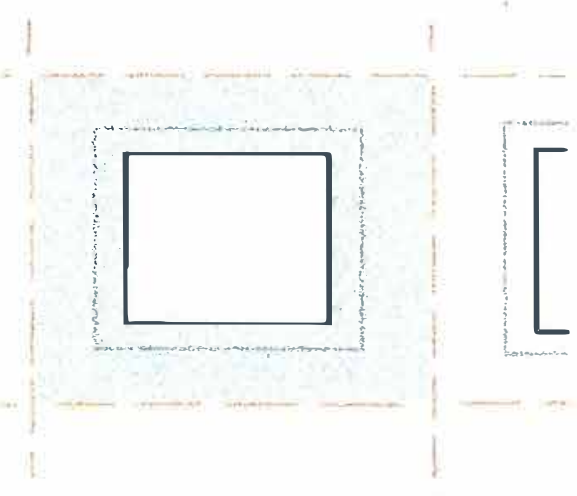

Figura 5 - Representação da área total pertencente a um quarteirão. 
Nem todos os quarteirões sorteados nesse trabalho possuíam um formato regular, que permitisse calcular facilmente o total de quilômetros de calçada e o total de área pertencente aos quarteirões.

Alguns quarteirões possuíam uma de suas quadras com formato curvo e para que fosse possível o cálculo do total de quilômetros destas quadras e da área do quarteirão foi feita uma aproximação da curva em segmentos de reta, conforme demonstra o desenho da figura 6 .

Na figura 6a há o exemplo de um quarteirão (identificado pelo número 1) cuja quadra voltada para a Rua Paulo Pinheiro tem formato curvo e na figura 6 b vê-se esta mesma quadra segmentada em três retas.

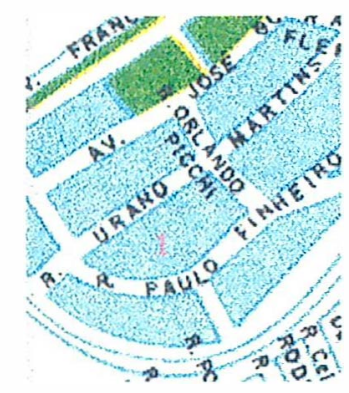

$6 \mathrm{a}$

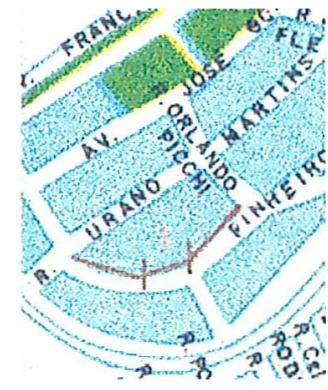

$6 \mathrm{~b}$

Figura 6 - 6a - Trecho do mapa de São Carlos mostrando um quarteirão (número 1) com uma quadra em forma de curva; $6 \mathrm{~b}$ - mesmo trecho do mapa mostrando a adaptação da quadra curva para segmentos de reta.

Admitiu-se como aceitável o erro embutido na estimativa tanto do total de quilômetros de calçada quanto do total de área de um quarteirão em casos como o apresentado na figura 6. Diante do fato de existir um erro inerente na medição dos comprimentos das quadras com o uso do mapa na escala 1:10.000, tornou-se irrelevante a precisão nos cálculos envolvendo largura de calçada e de rua. 


\subsection{Coleta dos dados}

De cada quarteirão selecionado para a amostra foram anotados o total de árvores existentes e suas características, o comprimento de cada quadra, a largura de cada calçada e a largura de metade de cada uma das ruas que delimitavam o quarteirão. Os dados foram coletados durante o ano de 1997.

No total de árvores foram incluídos todos os elementos arbóreos, arbustivos e herbáceos encontrados exclusivamente nas calçadas, em área de domínio público. Também foram inseridos no total de árvores os exemplares mortos e as covas abertas, mas sem árvore.

Além das duas variáveis principais definidas no item 3.3., as variáveis que descrevem a árvore de maneira qualitativa também foram objeto de estudo. Para isso foi usada uma ficha de coleta de dados baseada no formulário elaborado por Lima (1993). Na figura 7 tem-se esta ficha, que pode ser dividida em seis partes, cada parte contendo alguns itens subdivididos por categorias, conforme descritas a seguir.

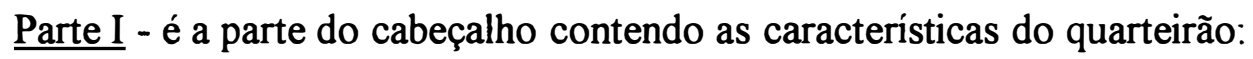

I.1 - número do quarteirão (Quarteirão) amostrado;

I.2- estrato (Estrato) no qual o quarteirão está inserido (para o caso de amostragem estratificada);

I.3 - bairro (Bairro) ao qual o quarteirão pertence.

Para cada uma das quadras era anotado:

I.4- nome da rua (Rua) à qual a quadra pertence;

I.5- seu comprimento em metros (Comp.). A medição do comprimento da quadra foi feita por meio do mapa de escala 1:10.000;

I.6- largura da rua (Larg.) dada em metros, cuja medição foi feita por meio de uma trena;

I.7- tipo (Tipo) de ocupação da quadra se refere à sua característica principal: residencial, comercial, de lazer, industrial, indefinida (quadras ainda sem ocupação, sem 


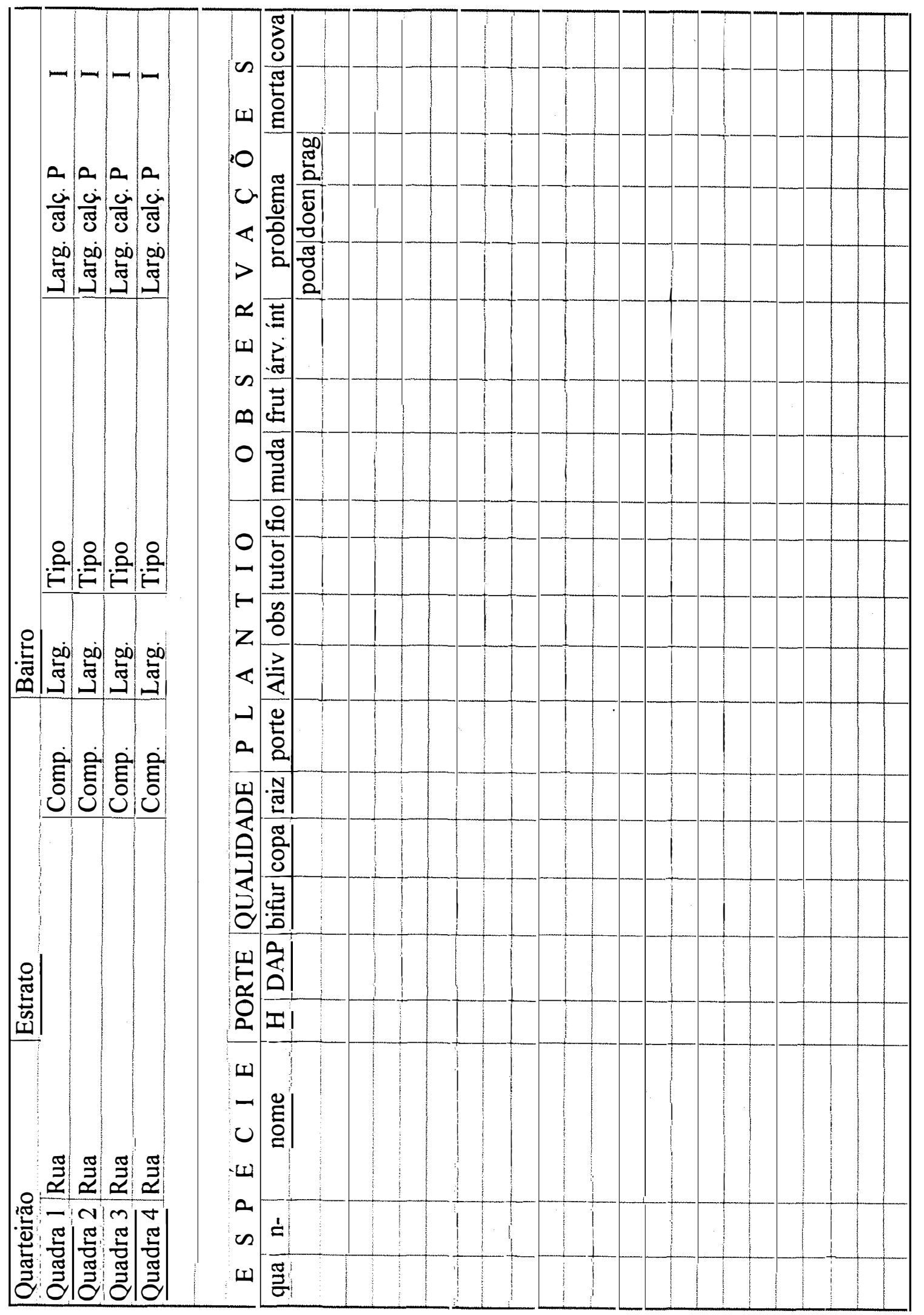


construção) etc.;

I.8- largura da calçada do lado par ou impar da rua, conforme a numeração das casas, dada em metros (Larg. calç. P I). O mesmo sistema de medição usado para largura da rua foi aqui adotado.

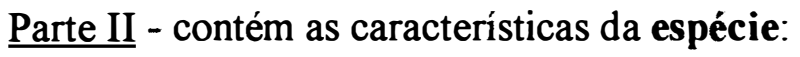

II. 1 - número da quadra (qua) à qual a árvore pertence;

II.2- número da árvore (n-), com uma numeração crescente a cada nova árvore encontrada. As árvores mortas e as covas sem árvore entravam na numeração;

ПI.3- nome da espécie.

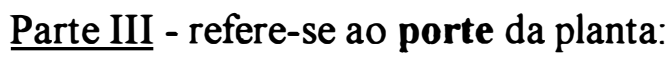

III.1 - a altura da árvore (H) foi medida em relação à fiação dos postes. A classificação foi feita de acordo com os dados fornecidos pela CPFL e pela TELESP de São Carlos sobre a altura padrão da fiação dos postes em relação à calçada: na fiação primária é de 8,20 metros e na fiação dos telefones é de 4,50 metros. Com isso, a classificação ficou estabelecida como:

1 - árvores abaixo da fiação dos telefones,

2- árvores entre a fiação dos telefones e a fiação primária,

3- árvores acima da fiação primária;

III.2- diâmetro à altura do peito (DAP) dado em centímetros e determinado pela medição da circunferência à altura do peito por meio de uma fita métrica.

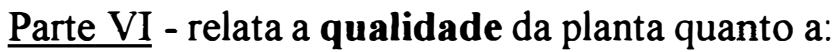

IV.1 - altura da bifurcação da árvore (bifur):

1- árvores bifurcadas a uma altura que atrapalhava a passagem de pedestres e veículos,

2- árvores bifurcadas a uma altura que não atrapalhava a passagem de pedestres e veículos; 
IV.2- condição da copa (copa) segundo a classificação:

1- copa com aspecto ruim, atípico, devido a problemas como queda ou amarelecimento das folhas, presença de praga ou doença, poda drástica descaracterizando o formato da copa, entre outros,

2- copa com aspecto razoável, com danos menos severos,

3- copa vigorosa, em estado sadio;

IV.3- condição da raiz (raiz) segundo a classificação:

1- raiz prejudicando severamente a calçada,

2- raiz começando a prejudicar a calçada,

3- raiz sem causar danos à calçada.

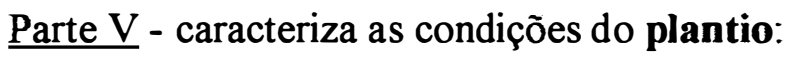

V.1- porte da espécie em relação ao espaço disponível no local (porte). A classificação deste item foi:

1 - árvore totalmente inadequada para o local por fatores como presença de fiação principal, proximidade com a residência, sistema radicular da espécie muito agressivo, frutos muito grandes etc,

2 - árvore parcialmente adequada ao local, mas havendo algum aspecto desfavorável,

3- árvore adequada ao local;

V.2- área livre junto ao tronco (Aliv) foi classificada em:

1- sem nenhuma ou com pouquíssima área de solo exposto,

2- área livre pequena, com uma área de solo disponível igual ao espaço já ocupado pelo tronco da árvore,

3- boa área livre, permitindo o escoamento da água da chuva ou irrigação e trocas gasosas do sistema radicular;

V.3- obstáculo (obs) próximo à árvore que pudesse atrapalhar o crescimento desta ou ainda ser motivo para o corte da mesma. Os obstáculos foram classificados em:

01- esquina, 


$$
\begin{aligned}
& 02 \text { - garagem, } \\
& 03 \text { - orelhão, } \\
& 04 \text { - poste, } \\
& 05 \text { - placa, } \\
& 06 \text { - encanamento, } \\
& 07 \text { - outra planta na mesma cova, } \\
& 08 \text { - suporte de lixo, } \\
& 09 \text { - marquise, } \\
& 10 \text { - bueiro, } \\
& 11 \text { - gradil de proteção, } \\
& 12 \text { - entulho; }
\end{aligned}
$$

V.4- tutor junto à árvore só era classificado como presente (s) quando realmente estivesse cumprindo a função de conduzir o crescimento da planta; quando não, a notação foi n;

V.5- fiação elétrica sobre a árvore (fio) quando presente recebia notação $\mathrm{s}$, quando ausente notação $n$.

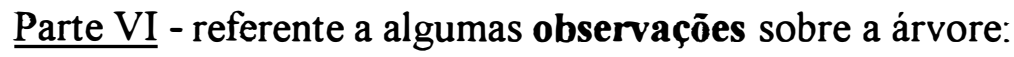

VI.1- se a árvore era uma muda (notação s) ou não (notação n);

VI.2- se era uma espécie frutífera (frut) para o homem (notação s) ou não (notação n);

VI.3- se o elemento (árv ínt), conhecidas as características da espécie, estava íntegro (notação s) ou não (notação $n$ );

VI.4- não se tratando de um elemento íntegro, procurou-se apontar o problema apresentado: poda, doença (doen) e/ou praga (prag). Cada uma destas categorias recebia uma classificação:

VI.4.1 - poda:

1- se a poda era drástica, descaracterizando a espécie, 
2- se o indivíduo não havia recebido poda de condução, atrapalhando, assim, a passagem de pedestres,

3- se se tratava de uma rebrota da árvore,

4 - se a poda da árvore estava mal feita; por exemplo, deixando uma parte do câmbio exposta;

VI.4.2- doença: notação s se o indivíduo apresentasse algum patógeno identificável ou algum sintoma abiótico como murchamento, amarelecimento ou queda de folhas e notação n se não apresentasse;

VI.4.3- praga: presença (notação s) de algum inseto ou planta parasita que comprometesse o desenvolvimento da árvore ou ausência de praga (notação n);

VI.5- árvore morta (notação s) ou não (notação n);

VI.6- existência (notação s) ou não (notação n) de cova aberta mas sem árvore plantada.

\subsection{Plano amostral dos métodos estudados}

\subsubsection{Amostragem casual simples}

Segundo COCHRAN (1977), para se estimar uma razão populacional deve-se usar estimadores do tipo razão, que são definidos como $R=\frac{X_{T}}{Y_{T}}$, sendo $X_{T}$ o valor populacional da característica "número de árvores existentes nos quarteirões" e $Y_{T}$ o valor populacional da característica "total de quilômetros de calçada" e da característica "total de hectares pertencentes aos quarteirões de uma cidade".

Tendo $N$ como o total de quarteirões da área de estudo, $n$ como o número de quarteirões selecionados para a amostra, $x_{i}$ como o valor da variável "número de árvores" e $y_{i}$ como o valor da variável "total de quilômetros" ou "total de hectares" do i-ésimo quarteirão sorteado, o intervalo de $95 \%$ de confiança para cada uma das razões populacionais é dado por: 


$$
(r-2 s(r), r+2 s(r)), \quad \text { sendo }
$$

$r=\frac{\sum_{i=1}^{n} x_{i}}{\sum_{i=1}^{n} y_{i}}$ a razão amostral;

- $s^{2}(r)=\frac{1-f}{\bar{y}^{2}(n-1)}\left(\sum_{i=1}^{n} x_{i}^{2}-2 r \sum_{i=1}^{n} x_{i} y_{i}+r^{2} \sum_{i=1}^{n} y_{i}^{2}\right) \quad$ a variância amostral;

- $f=\frac{n}{N} \quad$ a fração amostral;

- $\bar{y}=\frac{\sum_{i=1}^{n} y_{i}}{n}$ o valor médio da variável "total de quilômetros" ou "total de hectares".

O tamanho da amostra sorteada foi de $10 \%$ do tamanho da população; essa escolha foi inteiramente arbitrária, uma vez que na literatura específica sobre estatística não existe referência para a determinação do tamanho ótimo de amostra para estimadores do tipo razão.

Do total de 243 quarteirões sorteados, fizeram parte efetivamente do levantamento dos dados 230 quarteirões, pois desse total sorteado tiveram que ser descontadas aquelas unidades amostrais que eram compostas exclusivamente por área verde (praças, por exemplo), aquelas que existiam no mapa mas ainda não estavam delimitadas no campo e aquelas que existiam no campo mas possuíam um traçado completamente diferente do representado no mapa, inviabilizando assim a medição do comprimento das quadras. Com isso, o tamanho real da amostra foi de $9,4 \%$ do tamanho da população.

O tamanho de amostra de $9,4 \%$ foi considerado suficiente perante 0 critério, comumente adotado em trabalhos dessa natureza, de que o erro amostral das duas variáveis principais não fosse maior do que $10 \%$. 
O mapa contendo os quarteirões sorteados neste método está na figura 8.

\subsubsection{Amostragem estratificada}

A variável auxiliar empregada para estratificar a área de estudo deste trabalho foi o nível sócio-econômico da população de São Carlos. A escolha desta variável partiu da hipótese de que bairros mais ricos teriam um nível de escolaridade maior e com isso também uma preocupação maior com a qualidade de vida do ambiente, refletindo, assim, num nível de arborização de ruas maior do que aquele encontrado em bairros mais pobres.

O método de amostragem estratificada foi aplicado na área de estudo com o objetivo de verificar se a estratificação por níveis sócio-econômicos resultaria numa estimativa mais precisa do índice de arborização das ruas que a obtida com o método de amostragem casual simples.

A divisão da área de estudo em estratos foi baseada em um mapa denominado "Mapa da Exclusão em São Carlos", que faz parte da atividade de divulgação do projeto "Indicadores Sociais das Cidades Médias Paulistas", cuja coordenadora é a Prof ${ }^{\text {. Dr }}$. Elza de Andrade Oliviera do Departamento de Ciências Sociais da Universidade Federal de São Carlos.

Esse mapa foi montado a partir do cadastro censitário do IBGE de São Carlos de 1991 e baseou-se no valor do IPTU das propriedades pertencentes aos diversos setores censitários. Na figura 9 vê-se o mapa contendo a numeração dos setores censitários (cada número do mapa corresponde a um setor censitário) distribuídos em cinco diferentes cores. Cada cor representa uma categoria que descreve o intervalo, em porcentagem, de chefes de familia que ganham acima de 20 salários-minimos. 


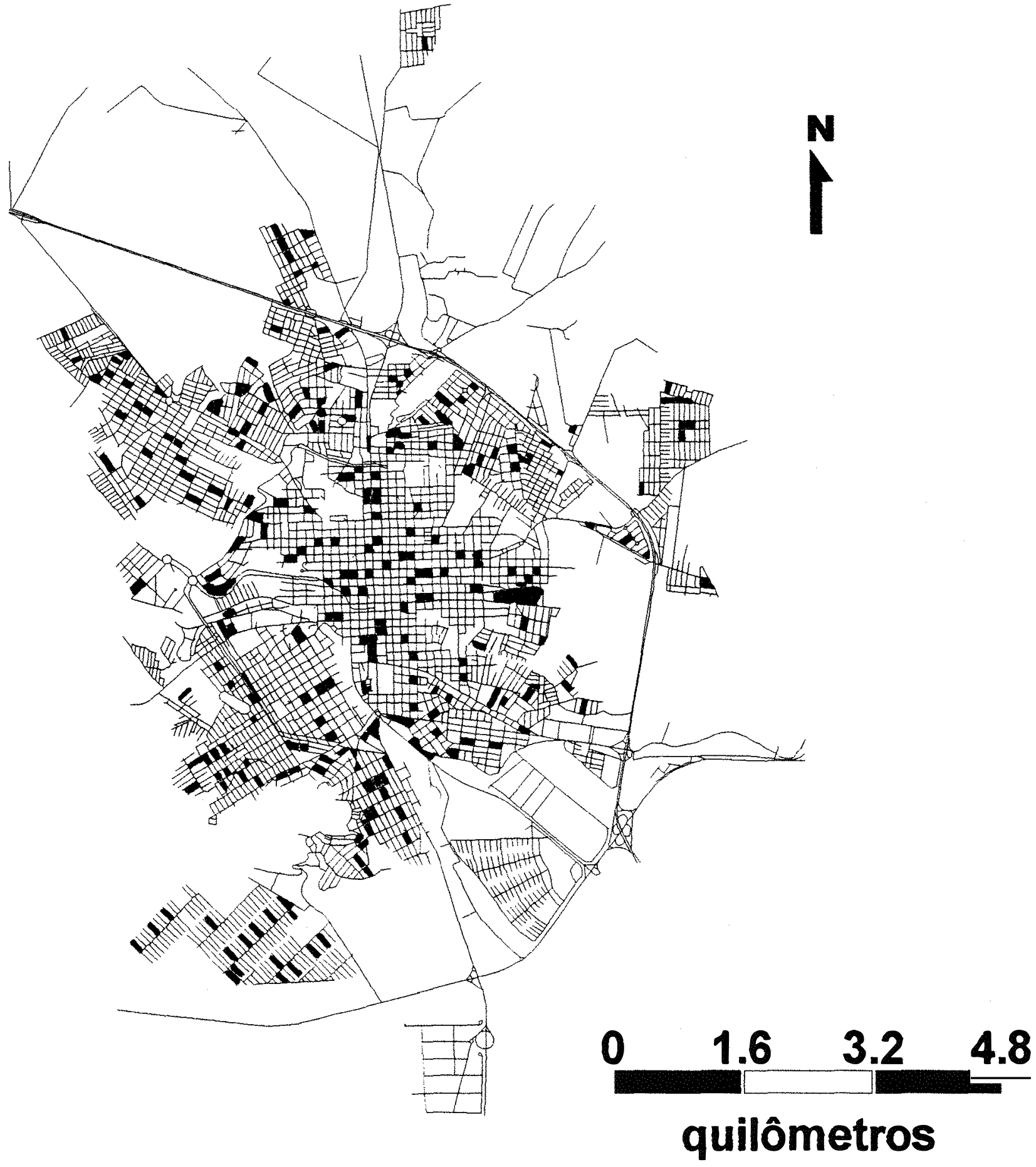

Figura 8 - Mapa de São Carlos com os quarteirões sorteados na amostragem casual simples. (Autores do mapa: Prof. Dr. Antonio Nélson Rodrigues da Silva, Eng ${ }^{a}$ Cynthia P. Lotti, Eng ${ }^{a}$. Sandra A. Margarido e Enga . Vânia M. P. Pampolha). 


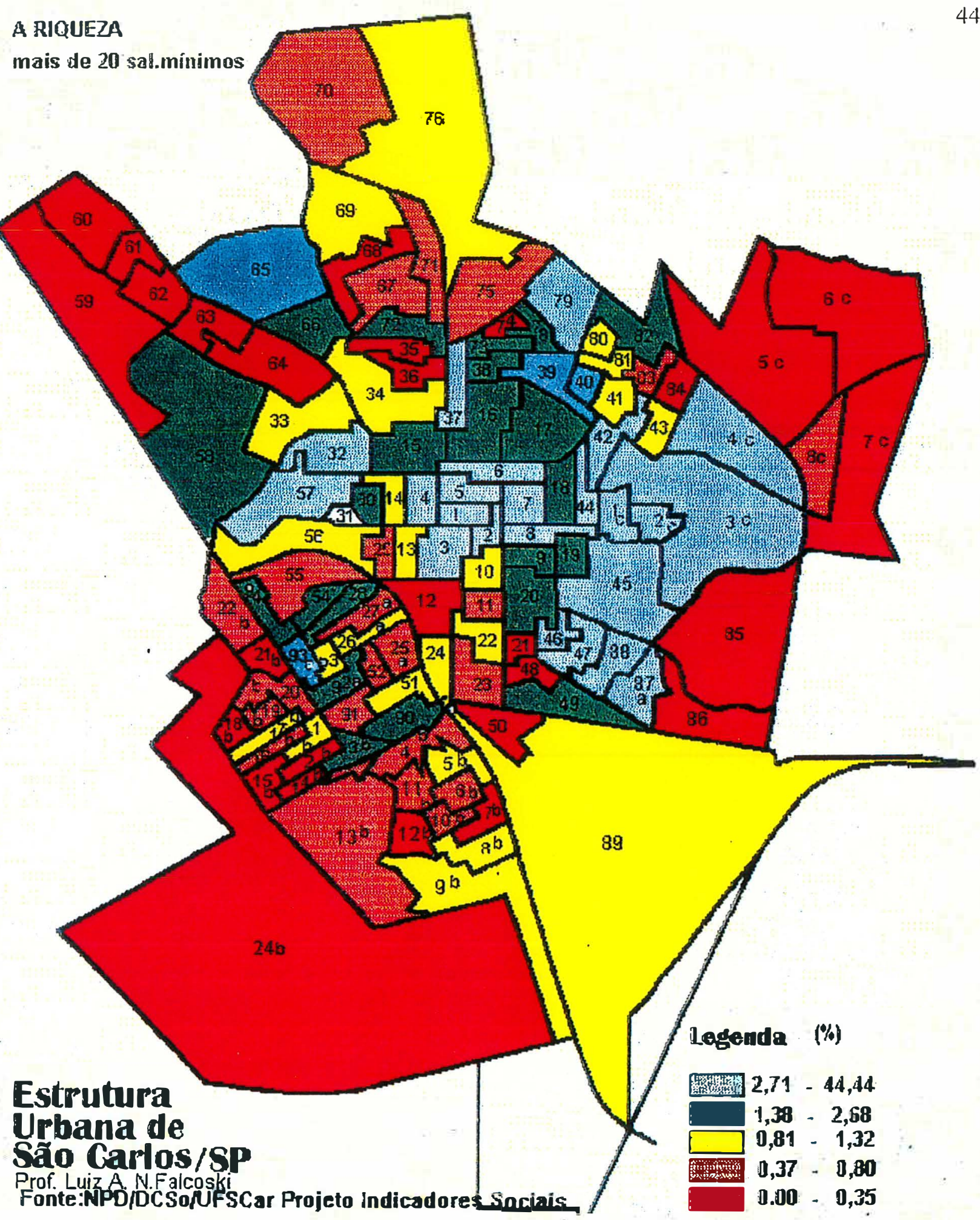

Figura 9 - "Mapa da Exclusão em São Carlos" com as cinco categorias (azul, verde, amarelo, laranja e vermelho) correspondentes à porcentagem de chefes de família que ganham acima de 20 salários-mínimos e que neste trabalho figuraram como os cinco estratos. 
Como o sistema de informações utilizado nesse trabalho de amostragem é mais recente, não figuram no "Mapa da Exclusão em São Carlos" os bairros Samambaia Residencial, Parque Faber, Recreio dos Bandeirantes e São Carlos VI. Estes quatro bairros constavam do mapa usado na amostragem casual simples, desse modo, eles não poderiam ser excluídos da amostragem estratificada a fim de que o levantamento dos dados fosse feito a partir de sistemas de informações idênticos. Por essa razão, eles foram incluídos em duas categorias a critério próprio, sem prejuízo para o resultado do projeto já citado. Os bairros Samambaia Residencial e Parque Faber foram incluídos na categoria de cor azul e Recreio dos Bandeirantes e São Carlos VI na categoria de cor vermelha.

Para o trabalho aqui desenvolvido, cada categoria figurou como um estrato.

O estrato azul contém o maior número de chefes de família ganhando acima de 20 salários-mínimos, conseqüentemente aí são encontrados os bairros mais luxuosos, como por exemplo, Parque Santa Mônica, Parque Santa Marta, Jardim Cardinalli e os condomínios fechados. A região mais antiga da cidade, o Centro, também pertence a este estrato e nele estão concentrados os bancos, o Mercado Municipal, a Catedral, as lojas e os casarões do início da colonização do município.

O segundo estrato com maior número de chefes de família com maior poder aquisitivo é o verde, que também abriga bairros de alto padrão como o Planalto Paraíso e a Vila Elisabeth. A maioria dos edificios residenciais, que começaram a ser construídos em grande número a partir da década de 80 , localizam-se no Centro (estrato azul) e na porção do estrato verde que circunda o Centro.

No estrato amarelo são encontradas várias indústrias, alguns bairros que fazem o limite da cidade, como a Vila Conceição, parte do Jardim Cruzeiro do Sul e parte do Jardim Jockey Club. O campus da Universidade de São Paulo localiza-se neste estrato.

Já se afastando do centro são encontrados os bairros do estrato laranja, onde se localizam alguns importantes pontos de referência na cidade, tais como, 0 aeroporto, o cemitério municipal e a indústria Electrolux. 
Grande parte dos bairros mais novos de São Carlos, loteados a partir da década de 80 , estão no estrato vermelho. Este estrato abrange a maioria dos bairros periféricos e dos bairros mais pobres. Nele é possível encontrar bairros que já possuem infra-estrutura mas têm baixo percentual de ocupação, como é o caso do Residencial Itamarati e outros, que são intensamente ocupados mas ainda carecem de melhorias como encanamento de esgoto e rua asfaltada - caso da Cidade Aracy.

$\mathrm{O}$ tamanho dos estratos ficou assim estabelecido: estrato azul com um total de 541 quarteirões, o verde com 380, o amarelo com 407, o laranja com 361 e o vermelho com 749 .

O estimador usado na amostragem estratificada foi o mesmo da amostragem casual simples, ou seja, estimador do tipo razão. Para manter a mesma relação tamanho de amostra/tamanho da população da amostragem casual simples, foi usada a estratificação de tamanho proporcional ao tamanho do estrato.

A seleção das unidades amostrais dentro de cada estrato foi feita por amostragem casual simples, sendo o tamanho de cada amostra correspondente a $10 \%$ do total de quarteirões existentes no estrato.

De acordo com COCHRAN (1977), quando o tamanho da amostra não é muito pequeno, é mais indicado utilizar como estimador da razão populacional a chamada razão separada, que é expressa por:

$$
\hat{R}_{e s}=\frac{\left(\sum_{h=1}^{H} \frac{x_{h}}{y_{h}} Y_{h}\right)}{Y_{T}}, \quad \text { da qual se identificam os seguintes termos, }
$$

- $x_{h}=\sum_{i=1}^{n_{h}} x_{i h}$, sendo $x_{i h}$ o valor da variável "número de árvores" do $i$-ésimo quarteirão sorteado no $h$-ésimo estrato;

- $y_{h}=\sum_{i=1}^{n_{h}} y_{i h}$, sendo $y_{i h}$ o valor da variável "total de quilômetros de calçada" ou "total de hectare" do $i$-ésimo quarteirão sorteado no $h$-ésimo estrato; 
- $Y_{h}=\sum_{j=1}^{N_{h}} Y_{j h}$, que corresponde ao total populacional da variável "total de quilômetros de calçada" / "total de hectare" no $h$-ésimo estrato, sendo $N_{h}$ o total de quarteirões no $h$-ésimo estrato e $Y_{j h}$ o valor da variável "total de quilômetros de calçada" / "total de hectare" do $j$-ésimo quarteirão sorteado no $h$-ésimo estrato;

- $Y_{r}=\sum_{h=1}^{H} Y_{h}$, que corresponde ao total populacional da variável "total de quilômetros de calçada" / "total de hectare".

A variância estimada do estimador de razão separada é dada por:

$$
s^{2}\left(\hat{R}_{e s}\right)=\frac{\left(\sum_{h=1}^{H} \frac{N_{h}^{2}\left(1-f_{h}\right)}{n_{h}}\left(s_{x h}^{2}+r_{h}^{2} s_{y h}^{2}-2 r_{h} s_{x y h}\right)\right)}{Y_{T}^{2}}, \quad \text { sendo }
$$

- $N_{h}$ o número de quarteirões no $h$-ésimo estrato;

- $\boldsymbol{n}_{h}$ o número de quarteirões sorteados no $h$-ésimo estrato;

- $f_{h}=\frac{n_{h}}{N_{h}}$ a fração amostral do $h$-ésimo estrato;

- $s_{x h}^{2}=\frac{1}{n_{h}-1} \sum_{i=1}^{n_{h}}\left(x_{i h}-\bar{x}_{h}\right)^{2}$ a variância da variável "número de árvores" do $h$-ésimo estrato;

- $r_{h}=\frac{x_{h}}{y_{h}}$ a razão amostral do $h$-ésimo estrato;

- $s_{y h}^{2}=\frac{1}{n_{h}-1} \sum_{j=1}^{n_{h}}\left(y_{i h}-\bar{y}_{h}\right)^{2}$ a variância da variável "total de quilômetros de calçada" $/$ "total de hectare" do $h$-ésimo estrato; 
- $s_{x y h}=\frac{1}{n_{h}-1} \sum_{j j=1}^{n_{h}}\left(x_{j h}-\bar{x}_{h}\right)\left(y_{j h}-\bar{y}_{h}\right)$ a covariância.

O intervalo de $95 \%$ de confiança para cada uma das razões populacionais foi obtido a partir da expressão:

$$
\left(\hat{R}_{e s}-2 s\left(\hat{R}_{e s}\right), \hat{R}_{e s}+2 s\left(\hat{R}_{e s}\right)\right)
$$

Assim como no método anterior, na amostragem estratificada foram sorteados ao todo 243 quarteirões. Mas do total sorteado, 219 quarteirões foram efetivamente medidos, pelos mesmos motivos apresentados no item 2.5.1. No estrato azul foram levantados 48 quarteirões, no verde 36, no amarelo 36, no laranja 32 e no vermelho 67 , o que correspondeu a um tamanho real de amostra de $8,9 \%, 9,5 \%, 8,8 \%$, $8,9 \%$ e $8,9 \%$, respectivamente.

Os tamanhos de amostra acima citados foram considerados suficientes perante o critério, comumente adotado em trabalhos dessa natureza, de o erro amostral das duas variáveis principais não ser maior do que $10 \%$.

O mapa contendo os quarteirões sorteados neste método está na figura 10 .

Para a análise dos dados foram usados os programas Microsoft Excel para Windows 95 e o sistema SAS (Statistical Analysis System). 


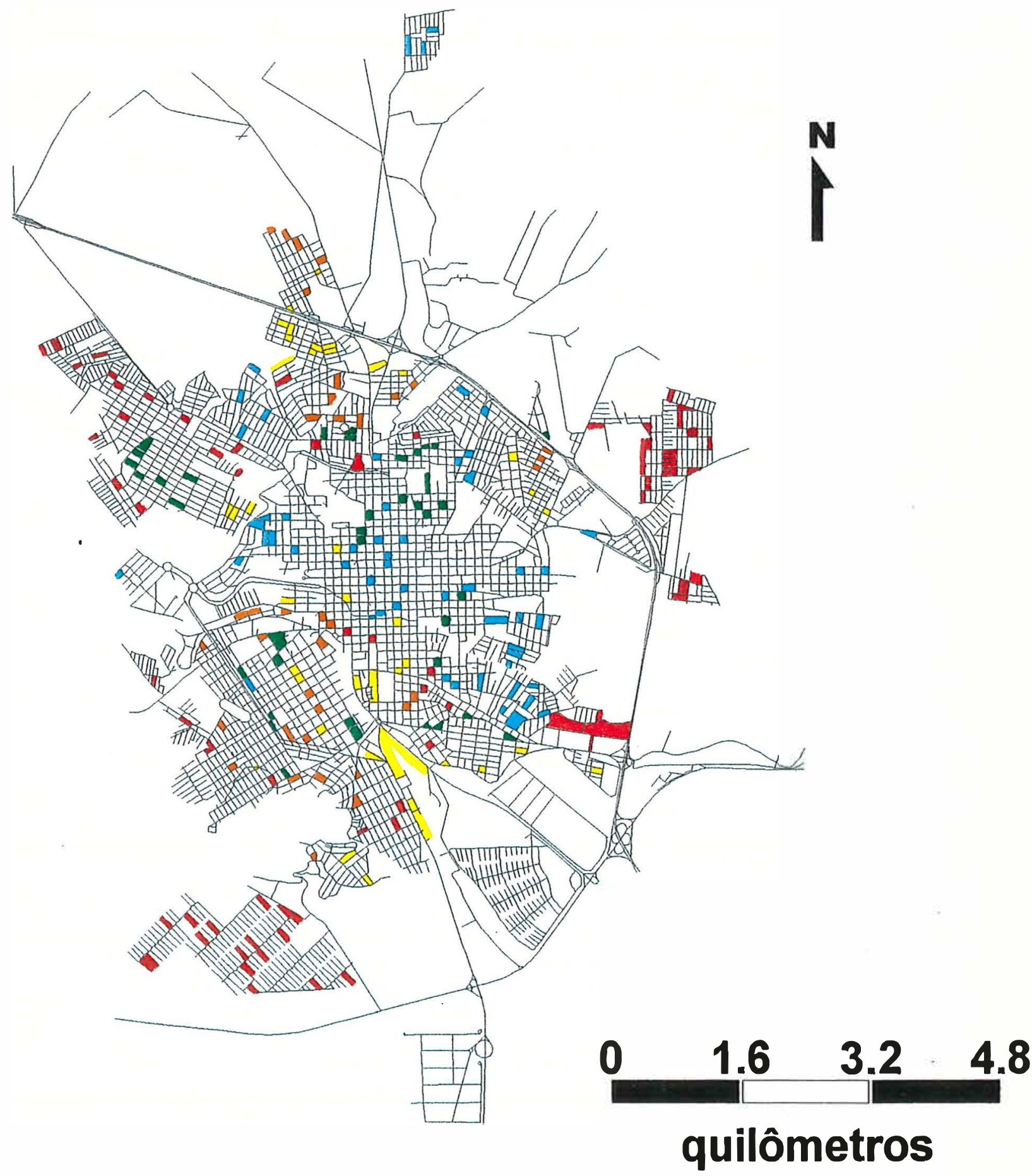

Figura 10 - Mapa de São Carlos com os quarteirões sorteados na amostragem estratificada. (Autores do mapa: Prof. Dr. Antonio Nélson Rodrigues da Silva, Enga Cynthia P. Lotti, Enga Sandra A. Margarido e Eng ${ }^{a}$ Vânia M. P. Pampolha). 


\section{RESULTADOS E DISCUSSÃO}

\subsection{Variável "número de árvores por quilômetro de calçada"}

\subsubsection{Amostragem casual simples}

Nos 230 quarteirões que fizeram parte da amostra correspondente a 9,4\% do tamanho da população foram medidos 2.958 elementos (árvores, arbustos, plantas mortas e covas) num total de 98,21 quilômetros de calçada. Com a amostra selecionada obteve-se uma estimativa dada pelo estimador razão de 30,12 árvores por quilômetro de calçada e uma variância de 2,09 . O intervalo de $95 \%$ de confiança foi de $(27,24 ; 33,00)$ e o erro amostral foi de $9,6 \%$.

\subsubsection{Amostragem estratificada}

$\mathrm{Na}$ amostragem estratificada foram medidos ao todo 219 quarteirões ou aproximadamente $9 \%$ do tamanho da população. Foram analisados, incluindo os cinco estratos, 2.689 elementos num total de 97,01 quilômetros de calçada. A estimativa dada pelo estimador razão para esta variável foi igual a 27,78 árvores por quilômetro de calçada, com uma variância de 1,95 . O intervalo de $95 \%$ de confiança foi de $(24,98$; $30,58)$ e o erro amostral foi de $9,9 \%$. 


\subsection{Variável "número de árvores por hectare"}

\subsubsection{Amostragem causal simples}

A mesma amostra de 230 quarteirões citada no item 4.1.1 resultou na medição dos 2.958 elementos num total de 64,76 hectares. A estimativa dada pelo estimador razão para esta variável foi igual a 45,68 árvores por hectare, com um valor de variância de 4,75 . O intervalo de $95 \%$ de confiança foi de $(41,32 ; 50,04)$ e o erro amostral foi de $9,5 \%$.

\subsubsection{Amostragem estratificada}

A amostra composta por 219 quarteirões permitiu a medição dos 2.689 elementos num total de 63,36 hectares. A estimativa dada pelo estimador razão foi de 42,46 árvores por hectare, com uma variância de 4,28. O intervalo de $95 \%$ de confiança foi de $(38,32 ; 46,60)$ e o erro amostral foi de $9,7 \%$.

As tabelas 1 e 2 mostram os resultados apresentados anteriormente.

Tabela 1 - Resultado da análise estatística obtida com a variável "número de árvores por quilômetro de calçada"

\begin{tabular}{ccc}
\hline $\begin{array}{c}\text { Variável "número de } \\
\text { árvores/km de calçada" }\end{array}$ & $\begin{array}{c}\text { Amostragem } \\
\text { Casual Simples }\end{array}$ & $\begin{array}{c}\text { Amostragem } \\
\text { Estratificada }\end{array}$ \\
\hline Estimador Razão $\left(r, \hat{R}_{e s}\right)$ & 30,12 & 27,53 \\
Variância $\left(s^{2}(r), s^{2}\left(\hat{R}_{e s}\right)\right)$ & 2,09 & 1,86 \\
Intervalo de Confiança (I.C.) de $95 \%$ & $(27,24 ; 33,00)$ & $(24,80 ; 30,26)$ \\
Erro Amostral & $9,6 \%$ & $9,9 \%$ \\
\hline
\end{tabular}


Tabela 2 - Resultado da análise estatística obtida com a variável "número de árvores por hectare"

\begin{tabular}{ccc}
\hline Variável & Amostragem & Amostragem \\
"número de árvores/ha" & Casual Simples & Estratificada \\
\hline Estimador Razão $\left(r, \hat{R}_{e s}\right)$ & 45,68 & 42,25 \\
Variância $\left(s^{2}(r), s^{2}\left(\hat{R}_{e s}\right)\right)$ & 4,75 & 4,19 \\
Intervalo de Confiança (I.C.) de $95 \%$ & $(41,32 ; 50,04)$ & $(38,16 ; 46,34)$ \\
Erro amostral & $9,5 \%$ & $9,7 \%$ \\
\hline
\end{tabular}

Comparando os resultados obtidos com a variável "número de árvores por quilômetro de calçada" nas duas metodologias, nota-se que há pouca diferença entre os valores encontrados: 30 árvores por quilômetro de calçada para a amostragem casual simples e aproximadamente 28 árvores para a estratificada. $\mathrm{O}$ valor 1,86 para a variância da amostragem estratificada pouco diferiu do valor 2,09 obtido na amostragem casual simples. O erro amostral ficou abaixo dos $10 \%$ para as duas metodologias. Essas pequenas diferenças refletiram-se no intervalo de confiança.

Para a variável "número de árvores por hectare" os resultados foram semelhantes entre as duas metodologias, como se comprova na comparação entre os estimadores razão e as variâncias: na amostragem casual simples encontrou-se perto de 46 árvores por hectare e variância próxima de 5 e na estratificada foram 42 árvores por hectare e variância 4. O erro amostral foi menor que $10 \%$ tanto para a amostragem casual simples como para a estratificada. Novamente vê-se que as pequenas diferenças ficaram refletidas no intervalo de confiança.

A semelhança entre os resultados da amostragem casual simples e da amostragem estratificada, medida principalmente em relação à variância, indica que as duas metodologias são eficientes e podem ser empregadas em inventários de arborização de ruas em São Carlos. Porém, o ganho em precisão obtido com a estratificação por nível sócio-econômico foi muito pequeno, o que leva a concluir que a variável de estratificação 
escolhida - nível sócio-econômico - não tem influência sobre o nível de arborização das ruas de São Carlos.

Por outro lado, a estratificação é um instrumento que permite mapear com mais detalhes a arborização por regiões específicas, enfocando as características peculiares de cada uma delas.

As duas variáveis usadas para estimar abundância de árvores forneceram resultados satisfatórios, podendo ambas serem empregadas em inventários quantitativos. Entretanto, o manuseio da variável "número de árvores por quilômetro de calçada" é mais simples, uma vez que dispensa a medição de metade da largura das ruas que circundam um quarteirão e isto implica também em maior rapidez para calcular o estimador razão. Outra vantagem no emprego desta variável é permitir a comparação com os resultados dos trabalhos realizados nessa área.

Lima et al. (1990) encontraram para a cidade de Petrolina (PE) um índice de 13 árvores por quilômetro de calçada. Admitindo um espaçamento regular de 15 metros entre árvores, o número ideal de árvores por quilômetro de calçada, segundo os autores, deveria ser 67.

Nos quase 24.000 metros de calçada amostradas por Malavasi et al. (1995) foram encontrados 114 vegetais; segundo critério seguido pelos autores - uma árvore a cada 5 metros de calçada - há no centro de Itaguaí (RJ) um déficit de 4.686 árvores.

Ao aplicar-se o critério acima e estendê-lo para toda a cidade de São Carlos é possível verificar que esta tem um déficit de 178.092 árvores. Mas o déficit de árvores em São Carlos diminui drasticamente quando comparam-se os dados em relação ao critério adotado no trabalho de Lima et al. (1990); neste caso, São Carlos passa a ter 38.663 árvores a menos do que seria aconselhável. O total de árvores (incluindo as plantas mortas e as covas abertas) estimado para a cidade de São Carlos varia entre 28.556 e 34.595 .

Maringá (PR), que costuma ser apontada como um exemplo de cidade bem arborizada, possui, segundo Milano (1990), aproximadamente 755 quilômetros de 
calçadas arborizadas que somam em torno de 63.000 árvores (portanto, 83 árvores por quilômetro de calçada) de 75 espécies diferentes, regularmente distribuídas.

Além de quantificar as árvores existentes numa cidade, é importante conhecer a distribuição das mesmas, pois um índice de arborização considerado bom poderia encobrir uma falha no planejamento da arborização caso a porcentagem de quadras sem árvores fosse elevada.

Em São Carlos, 9,13\% do total de quarteirões amostrados pelo método casual simples não possuíam árvore, nem mesmo uma cova aberta. Quando a análise é feita com as quadras, constata-se que $36,3 \%$ do total das quadras não tinham árvores ou covas abertas.

Fazendo-se a distribuição por classes do número de elementos (incluindo plantas.vivas, mortas e covas abertas) existente por quadra para a amostragem casual simples verifica-se que $36,2 \%$ das quadras possuíam de 1 a 4 elementos, 23,2\% possuíam de 5 a 11 elementos e 4,3\% possuíam mais de 11 elementos por quadra.

Com a amostragem estratificada foram encontradas porcentagens de quadras sem árvore ou cova semelhantes à da amostragem casual simples. Na figura 11 há a distribuição por classes do número de elementos encontrado por quadra para cada um dos estratos.

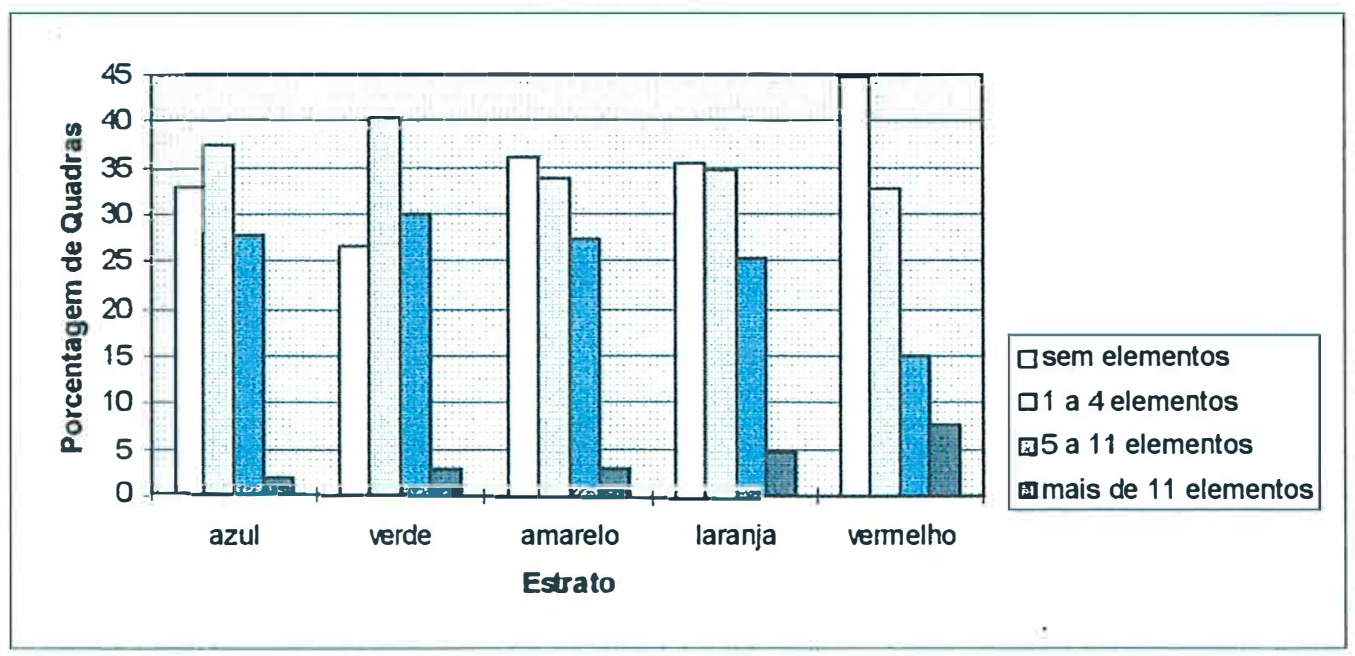

Figura 11 - Porcentagem de quadras para os elementos estudados (plantas vivas, mortas e covas) para cada um dos estratos amostrados. 
Nota-se que os estratos verde e vermelho tiveram os valores mais diferenciados de porcentagens de quadras sem árvores em relação aos demais estratos. Conforme será visto no item 3.4.2, o estrato verde - com a menor porcentagem de quadras sem árvores - também teve a menor porcentagem de quadras desocupadas, enquanto que o vermelho - com maior porcentagem de quadras sem árvores - teve a maior quantidade de quadras ainda sem ocupação.

Esta constatação aventa a hipótese de haver uma relação entre o índice de arborização e o tipo de ocupação das quadras, sugerindo como variável de estratificação a ser testada a "densidade de ocupação" dos bairros.

\subsection{Análise das variáveis qualitativas para amostragem casual simples}

\subsubsection{Variáveis comprimento de quadra, largura de rua, tipo de ocu- pação e largura de calçada}

O comprimento médio das quadras medidas na amostragem casual simples foi de 102,18 metros. Foram encontradas quadras desde 6 ate 490 metros, sendo os comprimentos de $50,60,90$ e 100 metros responsáveis por respectivamente $12,0 \%$, $13,7 \%, 19,5 \%$ e $5,4 \%$ do total medido.

A largura média das ruas amostradas em São Carlos foi de 8,24 metros e a largura média das calçadas foi de 2,29 metros. Estes valores médios obtidos para a cidade de São Carlos foram maiores que os encontrados por Lima (1993) em Piracicaba (SP), onde a largura média das vias e das calçadas (para ruas e avenidas sem canteiros centrais) foi, respectivamente, 6,3 e 2,0 metros.

Valores entre 2,0 e 2,5 metros foram as larguras de calçadas encontradas por Santos et al. (1995) em Bento Gonçalves (RS).

A maioria das quadras levantadas neste trabalho, $79,2 \%$, estavam ocupadas com residências, $9,7 \%$ do total tinham predominância de comércio, $7,1 \%$ foram classificadas como indefinida, pois ainda não possuíam ocupação, 2,2\% tinham escola, 
$1,2 \%$ eram quadras com indústria, $0,4 \%$ tinham construções com fins religiosos, uma quadra $(0,1 \%)$ era de lazer e outra $(0,1 \%)$ possuía serviços médicos.

Os locais predominantemente ocupados com comércio são, em geral, os mais problemáticos para implantação da arborização devido a fatores, tais como, intenso trânsito tanto de pessoas quanto de veículos e comerciantes que se sentem prejudicados com uma árvore tampando a fachada do seu estabelecimento. Portanto, são as áreas residenciais juntamente com as de instituição pública, principalmente as escolas, que poderiam contribuir com o aumento do índice de arborização de uma cidade, inclusive envolvendo moradores e alunos na vigilância e manutenção das árvores.

\subsubsection{Variável espécie}

Do total de 2.958 elementos analisados na amostragem casual simples, 2.461 foram de plantas vivas, englobando árvores e arbustos e também algumas plantas herbáceas.

Foram catalogadas 121 espécies diferentes, mas 45 dessas espécies estavam representadas com apenas um exemplar, como foi o caso do cedro, do guapuruvu, do angico e do jasmim-manga. $\mathrm{O}$ elevado número de espécies com apenas um exemplar, quase $40 \%$ do total, é um indício de que boa parte dos plantios de árvores nas calçadas tem sido feita por iniciativa da própria população.

A espécie mais freqüente foi a magnólia, com $24,95 \%$ do total de indivíduos, seguida por falsa-murta com $12,68 \%$ e aroeira-salsa com $9,47 \%$. A tabela 3 mostra os nomes científico e vulgar, a freqüência e a porcentagem de ocorrência das espécies com mais de 14 indivíduos.

Tabela 3 - Espécies analisadas na amostragem casual simples com mais de 14 indivíduos: nome científico, nome vulgar, freqüência e porcentagem.

\begin{tabular}{lccc}
\hline Nome científico & Nome vulgar & Freqüência & Porcentagem \\
\hline Michelia champaca $\mathrm{L}$. & magnólia amarela & 614 & 24,95
\end{tabular}


Tabela 3 - Espécies analisadas na amostragem casual simples com mais de 14 indivíduos: nome científico, nome vulgar, freqüência e porcentagem.

\begin{tabular}{|c|c|c|c|}
\hline Nome científico & Nome vulgar & Freqüência & Porcentagem \\
\hline Murraya paniculata Jack. & falsa-murta & 312 & 12,68 \\
\hline Schinus molle $\mathrm{L}$. & $\begin{array}{l}\text { aroeira-salsa, cha- } \\
\text { péu mexicano }\end{array}$ & 233 & 9,47 \\
\hline Caesalpinia peltophoroides Benth. & sibipiruna & 155 & 6,30 \\
\hline Bauhinia variegata $\mathrm{L}$. & pata-de-vaca & 155 & 6,30 \\
\hline Ficus benjamina $\mathrm{L}$. & figueira benjamim & 144 & 5,85 \\
\hline Terminalia catappa $\mathrm{L}$. & chapéu-de-sol & 101 & 4,10 \\
\hline Nectandra megapotamica (Spreng.) & canelinha & 95 & 3,86 \\
\hline \multicolumn{4}{|l|}{ Mez } \\
\hline Ligrstrum lucidum Ait. & alfeneiro & 77 & 3,13 \\
\hline Syagrus romanzoffiana (Cham.) & jerivá & 42 & 1,71 \\
\hline \multicolumn{4}{|l|}{ Glassman } \\
\hline \multicolumn{4}{|l|}{ DC.)Standl. } \\
\hline $\begin{array}{l}\text { Tabebuia avellanedae Lor. ex } \\
\text { Griseb. }\end{array}$ & ipê-roxo & 33 & 1,34 \\
\hline Licania tomentosa (Benth.) & oiti & 29 & 1,18 \\
\hline \multicolumn{4}{|l|}{ Fritsch. } \\
\hline Spathodea campamulata Beauv. & espatódea & 27 & 1,10 \\
\hline Eugenia jambolana Lam. & jambolão & 22 & 0,89 \\
\hline Lagerstroemia indica $\mathrm{L}$. & resedá & 21 & 0,85 \\
\hline Tabebuia roseo-alba (Ridl.) Sand. & ipê-branco & 20 & 0,81 \\
\hline Tïbouchina gramılosa Cogn. & quaresmeira & 17 & 0,69 \\
\hline Nerium oleander $\mathrm{L}$. & espirradeira & 15 & 0,61 \\
\hline Pachira aquatica Aubl. & monguba & 14 & 0,57 \\
\hline
\end{tabular}


Estas vinte espécies listadas constituem $87,97 \%$ do total de plantas estudadas na amostragem casual simples.

Resultado muito próximo ao deste trabalho foi o encontrado por Lima (1993) em Piracicaba, onde 20 espécies representaram 90\% do total de árvores levantadas. Lima et al. (1990) verificaram em Petrolina (PE) que das 71 espécies arbóreas-arbustivas identificadas, apenas 10 representavam $90 \%$ da população de árvores.

Em termos de distribuição de espécies, São Carlos está mais equilibrada que os bairros do centro de Piracicaba (Lima, 1993) e de Botucatu (Sousa et al., 1990), nos quais uma única espécie - Caesalpinia peltophoroides (sibipiruna) - foi responsável por, respectivamente, $52,3 \%$ e $70,6 \%$ do total de árvores.

Moll (1987) prega que a lista de árvores a serem plantadas numa cidade deve ser grande o suficiente para garantir diversidade de espécies, e também que uma única espécie não deve ocorrer com freqüência maior que $10 \%$.

Perante o critério acima, as espécies Murraya paniculata e Michelia champaca, sobretudo esta última, encontram-se com uma freqüência superior à recomendada; este fato deve ser levado em conta no planejamento dos próximos plantios em São Carlos.

Lima et al. (1990) alertam para o risco que a alta freqüência de uma única espécie pode representar caso surja um surto de uma praga ou doença com essa espécie; os autores constataram isso após levantamento feito em Petrolina, quando verificaram que $49,9 \%$ do total de espécies eram de Terminalia catappa.

Martins et al. (1992) levantaram em Viçosa as três espécies com maior freqüência, que foram o alfeneiro $(34,07 \%)$, o oiti $(14,78 \%)$ e a sibipiruna $(10,65 \%)$.

Talvez a situação mais parecida com a de São Carlos em termos de distribuição de espécies tenha sido a de Itaguaí (RJ), onde Malavasi et al. (1995) verificaram que as três espécies mais freqüentes foram Delonix regia com $26,31 \%$ do total de plantas, Mangifera indica com 14,91\% e Eugenia jambolana com 9,65\%. 


\subsubsection{Variáveis altura e DAP}

A análise da variável altura das plantas vivas apontou que 58,27\% delas possuíam altura classificada como 1 , ou seja, tinham até 4,50 metros, 39,21\% tinham altura 2 , entre 4,50 e 8,20 metros e somente $2,52 \%$ do total estavam na classe 3 , com mais de 8,20 metros de altura.

Chama a atenção o fato de mais da metade das plantas não ter atingido 4,50 metros de altura, mas é preciso considerar que nesta porcentagem estão incluídas as plantas novas, as plantas que não receberam poda de condução e as que estavam rebrotando depois de terem sido cortadas e que, portanto, ainda vão crescer. Além disso, também fazem parte da classe 1 as plantas de pequeno porte (em torno de $15 \%$ do total de plantas), que dificilmente ultrapassarão os 4,50 metros de altura.

O maior valor encontrado para a variável DAP foi 75,12 centímetros e o menor foi 0,19 com um valor médio igual a 13,67 centímetros. Do total de plantas, $7,52 \%$ tiveram o registro de DAP igual a zero, pelo fato de não terem atingido 1,30 metros de altura na época da medição; isso aconteceu com algumas mudas e com plantas que não sofreram poda de condução, apresentando-se com muitos galhos, porém abaixo de 1,30 metros de altura.

A seguir serão apresentados os dados das variáveis altura e DAP para as cinco espécies mais freqüentes.

De todas as magnólias medidas, $36,16 \%$ tinham até 4,50 metros de altura, $63,06 \%$ estavam entre 4,50 e 8,20 metros e apenas $0,65 \%$ delas estavam acima de 8,20 metros. O DAP mínimo e o máximo medidos para as magnólias foram, respectivamente, 0,80 e 37,56 centímetros, com valor médio igual a 15,91 centímetros. Em função do DAP médio e da baixa porcentagem de árvores acima de 8,20 metros de altura é possível afirmar que esta espécie ainda não atingiu o auge do seu tamanho. Por ser de grande porte, prevê-se que esta espécie demandará, num futuro próximo, grandes esforços com manutenção, uma vez que aproximadamente $48 \%$ delas estavam plantadas debaixo de fiação. 
Para 97,44\% dos arbustos da espécie Murraya paniculata (falsa-murta) a altura foi menor que 4,50 metros e somente $2,56 \%$ tinham entre 4,50 e 8,20 metros de altura. O menor DAP medido para as falsas-murtas foi 0,19 centímetros e o maior foi 21,65 , com valor médio igual a 4,09 centímetros. Trata-se de uma espécie bem adaptada a São Carlos e que dificilmente causa transtomos à calçada ou à fiação, porém é preciso lembrar que ela já está com uma freqüencia de ocorrência acima do desejável.

A maioria das árvores de Schinus molle (aroeira-salsa), 91,42\%, tinha menos de 4,50 metros de altura, 8,58\% delas tinham entre 4,50 e 8,20 metros e nenhuma árvore estava acima de 8,20 metros. Para esta espécie o menor e o maior DAP medidos foram, respectivamente, 0,32 e 23,87 centímetros e o DAP médio foi 6,95 centímetros. Os valores do DAP médio e da porcentagem de árvores abaixo de 4,50 metros indicam que as árvores desta espécie ainda são bem jovens, mas poderão causar problemas, pois crescem muito e são de dificil condução.

Das sibipirunas, $20,00 \%$ estavam com menos de 4,50 metros de altura, $66,45 \%$ estavam entre 4,50 e 8,20 metros e $13,55 \%$ estavam com mais de 8,20 metros. $O$ menor DAP medido para as sibipirunas foi 0,95 centímetros, o maior foi 57,61 e o DAP médio foi 26,92 centímetros. Pelo valor médio do DAP era de se esperar que houvesse uma porcentagem maior de sibipirunas com mais de 8,20 metros de altura; porém a maioria delas $(58,7 \%)$ estava sob fiação, o que acarreta numa alta porcentagem de árvores recebendo poda drástica para contenção da copa, conforme será visto adiante.

Apenas uma árvore da espécie Bauhinia variegata ficou acima de 8,20 metros de altura, $72,26 \%$ das árvores tinham entre 4,50 e 8,20 metros e $27,10 \%$ tinham até 4,50 metros de altura. Quanto aos valores do DAP, esta espécie apresentou resultados semelhantes ao da sibipiruna: o menor DAP medido nas baúnias foi 0,48 centímetros, o maior foi 41,70 e o DAP médio foi de 24,92 centímetros. Esta espécie foi a que teve a maior porcentagem de árvores podadas de maneira drástica, por conseqüência disso, teve uma baixíssima porcentagem de exemplares com altura superior a 8,20 metros. 


\subsubsection{Variáveis bifurcação, copa e raiz}

Atrapalhavam a passagem de pedestres e/ou veículos 40,15\% das árvores e arbustos plantados na calçada e $59,85 \%$ do total estavam bifurcadas em uma altura que não atrapalhava o trânsito em geral. A simples seleção das mudas que irão para as calçadas eliminaria em grande parte a necessidade de poda de condução das árvores depois do plantio, fazendo decair a porcentagem de plantas atrapalhando o trânsito.

Em Piracicaba, Lima (1993) encontrou uma situação melhor que a de São Carlos com relação à bifurcação das árvores, pois $80,5 \%$ do total de árvores não interferiam no trânsito de veículos e/ou pedestres.

A relação de plantas bifurcadas abaixo e acima do desejável para as cinco espécies mais freqüentes foi de 24,59\% e 75,41\% para as magnólias, 67,31\% e 32,69\% para as falsas-murtas, $64,81 \%$ e $35,19 \%$ para aroeiras-salsas, $10,97 \%$ e $89,03 \%$ para as sibipirunas e $5,16 \%$ e $94,84 \%$ para as patas-de-vaca. Das cinco espécies citadas, duas chamam a atenção pela elevada porcentagem de plantas bifurcadas abaixo do desejável, que são a falsa-murta e a aroeira-salsa; a primeira, por se tratar de um arbusto, precisa receber poda para que a copa se estabeleça a uma altura minimamente razoável e a segunda exige manutenção regular pois sua copa tem tendência para pender.

Outra espécie com porcentagem elevada de indivíduos interferindo no trânsito foi o Ficus benjamina, com um valor igual a 65,97\%. Apesar de ser uma espécie de grande porte e ter um sistema radicular muito agressivo, ela é a sexta espécie mais plantada nas ruas de São Carlos; mas como indica o dado acima, ela não tem sido podada no momento devido, fazendo com que a copa adquira volume em uma altura indevida.

As espécies oiti, quaresmeira e espirradeira possuíam a maioria dos exemplares, em torno de $70 \%$, bifurcados a uma altura aquém do desejável.

A análise da condição da copa das árvores e arbustos indicou que $12,84 \%$ das plantas estavam na classe 1 (aspecto atípico da copa), 27,35\% estavam na classe 2 (aspecto de copa razoável) e 59,81\% estavam na classe 3 (aspecto sadio da copa). O 
aspecto atípico é resultado, essencialmente, de poda drástica que o indivíduo recebeu, de corte e conseqüente rebrota do exemplar e ainda de doença causando perda de folhas.

As magnólias tiveram a copa classificada como 3 em $62,21 \%$ dos casos, em $24,60 \%$ tiveram classificação 2 e em $13,19 \%$ dos casos foram classificadas como 1 .

As espécies falsa-murta e aroeira-salsa obtiveram as maiores porcentagens de indivíduos com aspecto de copa típico; 70,51\% das falsas-murtas apresentaram copa classificada como 3, 20,51\% como 2 e 8,86\% como 1. Para as aroeiras-salsas a quantidade de plantas na classe 3 foi de $74,25 \%$, na classe 2 foi de $21,89 \%$ e na classe 1 foi de $3,86 \%$. A tendência para as falsas-murtas é de permanecer alta a porcentagem de plantas com copa típica, mas o mesmo não pode ser dito para as aroeiras-salsas: por ser uma espécie de plantio relativamente recente, são raros os exemplares que já apresentam um porte avantajado, portanto, ainda é baixo o índice de árvores podadas de maneira a descaracterizar o formato da copa.

A copa de $64,52 \%$ das sibipirunas tinha forma típica, $24,52 \%$ tinham copa com aspecto razoável e 10,96\% tinham copa atípica.

Situação crítica foi a encontrada para as patas-de-vaca, pois somente $16,77 \%$ das árvores estavam na classe 3, ou seja, tinham aspecto de copa típico; a maioria das árvores, $45,81 \%$, ficou com a copa na classe 2 e $37,42 \%$ das plantas tinham a copa desfigurada (classe 1).

A pata-de-vaca e também a magnólia, apresentaram os valores mais altos de copa com aspecto atípico, principalmente devído à poda; por serem árvores predominantes em épocas diferentes (a pata-de-vaca era a espécie mais comum nas ruas nos anos 70/80) e por serem de grande porte estão mais sujeitas a interferências, como por exemplo, poda.

Quanto à variável raiz, verificou-se que $5,08 \%$ do total de plantas possuíam raízes que estavam danificando a calçada (classe 1), 22,27\% possuíam raízes que estavam começando a danificar a calçada (classe 2 ) e 72,65\% delas possuíam raízes que não estavam danificando a calçada (classe 3 ). 
Não chega a ser preocupante o indice de plantas danificando a calçada, mas é imprescindível estar ciente de que muitas plantas ainda não atingiram seu tamanho máximo. Contribuiu também para este índice ser baixo o fato de muitos indivíduos estarem plantados em calçadas ainda não pavimentadas. Analisando conjuntamente altura e condição da raiz verifica-se que $54,84 \%$ dos indivíduos com mais de 8,20 metros estavam danificando ou começando a danificar o calçamento.

Por espécie a condição da raiz teve a seguinte distribuição: para as magnólias $55,37 \%$ estavam na classe 3,36,64\% na classe 2 e 7,98\% na classe 1; para as falsas-murtas $98,40 \%$ estavam na classe $3,1,60 \%$ na classe 2 e nenhuma na classe 1; para as aroeiras-salsas 90,56\% estavam na classe 3,9,01\% na classe 2 e apenas 1 planta na classe 1; para as sibipirunas 54,19\% estavam na classe 3, 31,61\% na classe 2 e $14,19 \%$ na classe $1 ; 54,84 \%$ das bauínias ficaram na classe 3, 43,22\% na classe 2 e 1,94\% na classe 1. Para as espécies magnólia e aroeira-salsa a porcentagem de plantas danificando a calçada tende a aumentar conforme o crescimento das mesmas. Assim como a sibipiruna, as espécies espatódea, chapéu-de-sol e mangueira alcançaram valores de árvores danificando calçadas próximos a $14 \%$.

Dentre totas as espécies, a que exibiu a maior porcentagem de exemplares danificando totalmente a calçada foi a Delonix regia (Boger) Raf. (flamboyant).

Em Viçosa (MG), 87,75\% das árvores não apresentavam danos às calçadas, segundo Martins et al. (1992). Santos et al. (1991) avaliaram que as espécies Ligustrum sp., Jacaranda mimosifolia e Cassia macranthera foram as que causaram a maior porcentagem de danos às calçadas de Bento Gonçalves (RS).

\subsubsection{Variáveis porte, área livre, obstáculo, tutor e fio}

Os resultados obtidos para a variável porte das árvores mostram que $32,55 \%$ do total de plantas eram inadequadas para o local do plantio (classe 1), 14,83\% eram parcialmente adequadas (classe 2 ) e 52,62\% eram adequadas para o local (classe 3 ). 
A grande contribuição ao total de árvores inadequadas para o local do plantio foi dada pelas espécies de grande porte, destacando-se entres elas a figueira benjamim, a monguba, o jambolão, o chapéu-de-sol e as frutíferas mangueira e abacateiro.

Metade das magnólias estava plantada em local adequado, 33,39\% foram consideradas inadequadas para o local e $16,12 \%$ foram consideradas parcialmente adequadas para o local.

Praticamente todas as falsas-murtas, $99,36 \%$, eram adequadas para o local onde foram plantadas, apenas um exemplar estava em local inadequado e um outro em local parcialmente adequado.

Mais de 50\% das aroeiras-salsas tinham algum tipo de restrição em relação ao local onde estavam plantadas: $21,46 \%$ eram parcialmente adequadas e $36,05 \%$ eram inadequadas para o local, e isso poderá acarretar transtornos no futuro; $42,49 \%$ eram adequadas para o local do plantio.

Também as sibipirunas contribuíram para elevar $o$ total de plantas inadequadas para o local do plantio, pois $52,90 \%$ delas eram inadequadas, valor em parte explicado pelo fato de quase $59 \%$ das árvores desta espécie estarem debaixo de fio. Para $34,19 \%$ das sibipirunas o local era adequado e para $12,90 \%$ o local era parcialmente adequado.

Um pouco mais da metade das patas-de-vaca, $52,26 \%$, eram adequadas ao local de plantio, $36,13 \%$ eram inadequadas e $11,61 \%$ eram parcialmente adequadas.

Quanto à área livre junto ao tronco foi detectado que 31,57\% das plantas tinham pouquíssima ou nenhuma área livre (classe 1), 46,52\% tinham uma pequena área livre ao redor do tronco (classe 2) e 21,91\% delas tinham uma boa área livre (classe 3). Somando-se plantas com pequena e nenhuma área livre chega-se a uma situação muito ruim - 78,09\% - quadro que poderia ser facilmente mudado apenas aumentando-se alguns centímetros na cova das árvores.

Não é só em São Carlos que se verifica o desleixo em relação ao espaço destinado a trocas gasosas do sistema radicular. Santos et al. (1991) detectaram que 19\% 
das plantas estudadas em Bento Gonçalves (RS) tinham área livre ampla contra 60,74\% que tinham área restrita ou inexistente. Martins et al. (1992) verificaram que apenas $5,86 \%$ das árvores de Viçosa tinham área livre ampla.

Das 2.461 plantas vivas analisadas, $92,00 \%$ não tinham obstáculo ao redor que pudesse atrapalhar o desenvolvimento ou que pudesse servir de motivo para cortá-las. Mas $77(3,13 \%)$ estavam plantadas a menos de 5 metros de um poste, $27(1,10 \%)$ estavam plantadas em cova onde havia outra planta, $19(0,77 \%)$ estavam próximas a uma garagem, $16(0,65 \%)$ foram plantadas sob marquise, $15(0,61 \%)$ foram plantadas muito próximas à esquina, $15(0,61 \%)$ estavam ao lado de encanamento, $12(0,49 \%)$ estavam localizadas muito próximas a uma placa de trânsito, $8(0,32 \%)$ estavam envolvendo a armação do suporte de lixo, $5(0,20 \%)$ estavam muito próximas a um bueiro e $2(0,08 \%)$ tinham o material do próprio gradil danificando a planta.

É preciso ter critério ao escolher o local onde vai ser plantada a muda de uma árvore pois se ela for colocada próxima a uma placa de trânsito, irá tampá-la quando sua copa adquirir volume; se for colocada junto a um poste com transformador, irá dificultar o trabalho de manutenção do mesmo; se for plantada rente a uma garagem, atrapalhará a entrada e saída de veículos; se for plantada sob uma marquise vai entortar o tronco à procura de luz, o que esteticamente não é aprazivel.

Do total de plantas analisadas, $90,98 \%$ não tinham tutor e $9,02 \%$ tinham um tutor que estava cumprindo a função de auxiliar no crescimento da planta.

Considerando-se apenas as plantas vivas verificou-se que $47,83 \%$ delas foram plantadas debaixo de fiação e $52,17 \%$ não tinham fio acima da cova. Acrescentado-se as árvores mortas e as covas sem árvore tem-se 1.590 ou $53,75 \%$ do total sob fiação e 1.368 ou $46,25 \%$ sem fiação por cima. A constatação de que quase metade das plantas estavam debaixo de fiação merece atenção, primeiro pelo fato de que não há necessidade disso visto que há espaço disponível nas calçadas livres de fios e depois por verificar-se no dia a dia que a cidade de São Carlos não tem uma equipe capacitada para fazer uma poda adequada nas árvores que estão sob fiação. 
No levantamento feito por Lima (1993) em Piracicaba também foi constatado um número elevado de plantas debaixo de fiação, $55,92 \%$ do total.

$\mathrm{Na}$ cidade de Petrolina, Lima et al. (1990) viram que $41 \%$ das árvores foram plantadas sob fiação.

\subsubsection{Variáveis muda, frutífera, íntegra, poda, doença, praga, morta e cova}

De todas as plantas vivas levantadas, $91,63 \%$ eram indivíduos jovens ou adultos e $8,37 \%$ eram mudas. A quantidade de mudas por espécie foi aproximadamente de $2 \%$ para as magnólias, $20 \%$ para as falsas-murtas, $13 \%$ para as aroeiras-salsas e apenas um indivíduo das espécies sibipiruna e pata-de-vaca era muda. Os dados mostram que a falsa-murta, a aroeira-salsa, a figueira benjamim, o alfeneiro e o ipê amarelo foram as espécies com maior porcentagem de mudas.

Não foram encontradas nas calçadas muitas plantas fornecedoras de frutos e sementes ao homem, elas representaram $2,84 \%$ do total de árvores e arbustos. Foram registradas 9 amoreiras, 8 limoeiros, 6 mangueiras, 5 amexeiras, 5 mamoeiros, 4 goiabeiras, 4 abacateiros, 3 pitangueiras, 3 pés de acerola, 3 pés de sirigüela, 2 cafeeiros, 2 romãnzeiras, 2 tamarindeiros, 2 pés de uva-do-japão e um exemplar de cada uma das seguintes plantas: laranjeira, jabuticabeira, coqueiro, bananeira, cajueiro, jaqueira, ateira, jambeiro, graviola, jurubeba e pinheiro-do-paraná.

A quantidade de plantas sadias encontradas neste levantamento foi equivalente a $72,61 \% ; 27,39 \%$ das plantas apresentaram algum problema.

Lima et al. (1990) observaram em Petrolina um valor de árvores sadias menor que o de São Carlos: $63 \%$ foram classificadas como boa, 33\% satisfatória, $3 \%$ ruim e $1 \%$ morta ou em estado irrecuperável.

Santos et al. (1991) analisaram a arborização central de Bento Gonçalves e constataram que $64,80 \%$ dos indivíduos estavam íntegros. 
Tiveram problemas relativos a poda $23,81 \%$ das plantas, subdivididos nas seguintes categorias: $10,36 \%$ não receberam poda de condução e estavam atrapalhando a passagem de pedestres e/ou veículos, 9,96\% sofreram poda drástica, descaracterizando a planta, $1,91 \%$ tiveram o tronco cortado com a intenção de serem eliminadas, mas estavam rebrotando com vigor e $1,58 \%$ sofreram danos no câmbio em conseqüência de poda mal feita.

A realização de poda drástica, deformando a copa e a forma das árvores foi observada por Lima et al. (1990) em 16\% dos indivíduos plantados nas ruas de Petrolina.

Tanto as magnólias quanto as falsas-murtas não tiveram problemas relativo a poda em $80,13 \%$ dos exemplares. Naquelas magnólias em que houve problema, o mais freqüente foi de poda drástica, $9,28 \%$ dos casos, e de falta de poda de condução em $6,19 \%$ das árvores. Para as falsas-murtas, $15,70 \%$ deveriam ter recebido poda de condução.

Para as aroeiras-salsas obteve-se o seguinte resultado: $24,46 \%$ deveriam ter sido podadas para melhor conduzir o crescimento das árvores e $72,96 \%$ do total das plantas não tiveram problemas com poda.

Não tiveram problema com poda $75,48 \%$ das sibipirunas e quando o problema ocorreu com maior freqüencia atingiu $20,00 \%$ das árvores, caracterizado por poda drástica. Valores de indivíduos podados semelhantes ao das sibipirunas foram medidos para as espatódeas e para os chapéus-de-sol.

Situação grave ocorreu com as patas-de-vaca, pois apenas $28,39 \%$ delas não tiveram problemas relativos a poda. A maioria das árvores, $63,22 \%$, sofreram poda drástica, dado que comprova aquilo que é facilmente percebido, ou seja, a maioria das patas-de-vaca de São Carlos está desfigurada.

Doença foi detectada, porém não diagnosticada, em 58 plantas amostradas, o que correspondeu a $2,36 \%$ do total. Estavam doentes $2,93 \%$ das magnólias, $2,56 \%$ das falsas-murtas, $0,43 \%$ das aroeiras-salsas, $2,58 \%$ das patas-de-vaca 
e $1,29 \%$ das sibipirunas. A canelinha foi a espécie que teve o maior índice de plantas doentes, $10,53 \%$.

Foram atingidas por praga 55 plantas ou $2,23 \%$ do total analisado, sendo as mais comuns as cochonilhas, as saúvas, os pulgões e as cigarrinhas; erva-de-passarinho foi classificada como praga. Somente $0,81 \%$ das magnólias estavam com praga, já as falsas-murtas tiveram $4,17 \%$ de plantas com praga, as aroeiras-salsas $0,43 \%$, as patas-devaca $4,52 \%$ e as sibipirunas $7,10 \%$.

A tabela 4 contém o resultado de algumas variáveis analisadas para as cinco espécies mais freqüentes da amostragem casual simples.

Dos 2.983 elementos que compuseram a amostra, 265 eram de covas abertas mas sem árvore e 232 eram de plantas mortas, o que representou, respectivamente, $8,96 \%$ e $7,84 \%$ do total amostrado.

É alto o valor de plantas mortas em São Carlos quando comparado a Viçosa, onde Martins et al. (1992) encontraram um percentual de árvores mortas de 3,91\%. Ainda menor foi o encontrado por Santos et al. (1991) em Bento Gonçalves, onde $1,72 \%$ do total de indivíduos eram árvores mortas. 


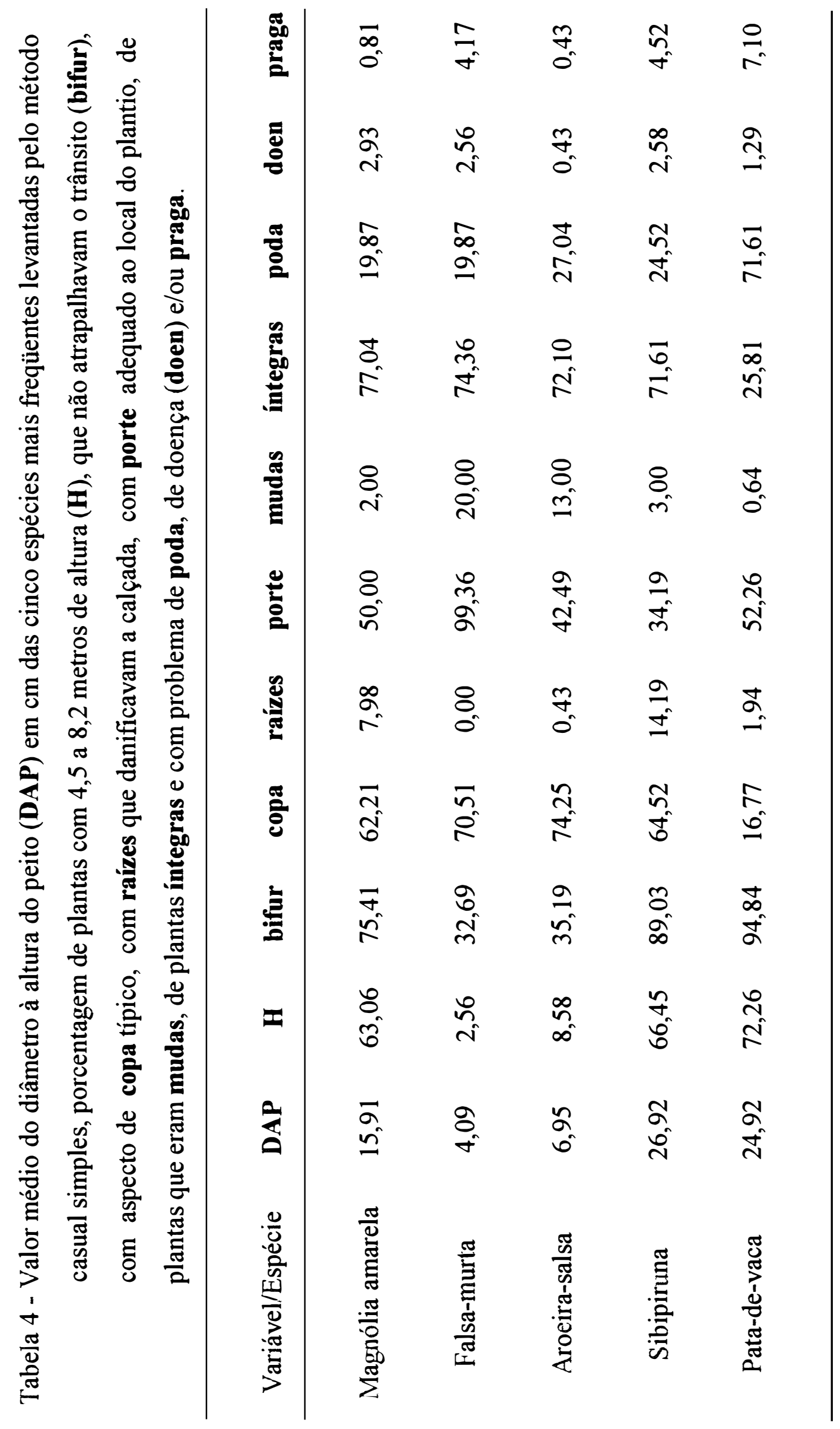




\subsection{Análise das variáveis qualitativas para amostragem estratificada}

\subsubsection{Estrato azul}

\subsubsection{Variáveis comprimento de quadra, largura de rua, tipo de ocupação e largura de calçada}

O comprimentro médio das quadras do estrato azul foi de 102,47 metros, com variação de 25 a 275 metros, sendo 90 metros o comprimento de $32,3 \%$ das quadras.

A média da largura das ruas analisadas foi de 8,45 metros e 2,39 metros foi a largura média das calçadas do estrato azul.

Quanto ao tipo de ocupação verificou-se que $78,1 \%$ das quadras eram residenciais, $13,1 \%$ eram comerciais, 7,3\% eram indefinidas (sem ocupação), 0,5\% (apenas uma quadra) era ocupada com serviço de saúde, $0,5 \%$ com lazer e $0,5 \%$ com serviços públicos.

\subsubsection{Variável espécie}

O total de elementos (plantas vivas, plantas mortas e covas) analisados neste estrato foi de 579 ou $21,49 \%$ do total de elementos de todos os estratos.

Foram analisadas 486 plantas vivas (árvores, arbustos e plantas herbáceas), distribuídas em 51 diferentes espécies, das quais 20 (39,22\%) possuíam apenas um indivíduo.

Neste estrato, as cinco espécies mais freqüentes foram as mesmas encontradas na amostragem casual simples: em primeiro lugar ficou a magnólia amarela com $16,05 \%$ do total de plantas, seguida por falsa-murta com $12,76 \%$ e por aroeira-salsa com 12,35\%. A relação das espécies com mais de 14 indivíduos está na tabela 5 . 
Tabela 5 - Espécies analisadas no estrato azul com mais de 14 indivíduos: nome científico, nome vulgar, freqüência e porcentagem.

\begin{tabular}{llcc}
\hline Nome científico & Nome vulgar & Freqüência & Porcentagem \\
\hline Michelia champaca $\mathrm{L}$. & magnólia amarela & 78 & 16,05 \\
Murraya paniculata Jack. & falsa-murta & 62 & 12,76 \\
Schimus molle L. & $\begin{array}{l}\text { aroeira-salsa, cha- } \\
\text { péu mexicano }\end{array}$ & 60 & 12,35 \\
& pata-de-vaca & 39 & 8,02 \\
Bauhinia variegata L. & sibipiruna & 31 & 6,38 \\
Caesalpinia peltophoroides Benth. & canelinha & 24 & 4,94 \\
Nectandra megapotamica (Spreng.) & figueira benjamim & 20 & 4,12 \\
Ficus benjamina L. & quaresmeira & 19 & 3,91 \\
Tibouchina gramulosa Cogn. & & & \\
Mez & resedá & 16 & 3,29 \\
Lagerstroemia indica L. & &
\end{tabular}

Observa-se que as espécies do estrato azul estão melhor distribuídas em relação àquelas da amostragem casual simples, porém as 3 primeiras já apresentam uma freqüência acima do recomendável pela literatura pertinente.

\subsubsection{Variáveis altura e DAP}

Das plantas vivas deste estrato, $53,91 \%$ tinham até 4,50 metros de altura (classe 1), 41,56\% tinham entre 4,50 e 8,20 metros de altura (classe 2) e 4,53\% tinham mais de 8,20 metros de altura (classe 3).

O valor médio conseguido para a variável DAP foi de 16,02 centímetros, sendo 65,25 o valor máximo encontrado e 0,32 centímetros o valor mínimo. Trinta e oito plantas $(7,82 \%)$ não tinham atingido 1,30 metros de altura no momento da medição. 


\subsubsection{Variáveis bifurcação, copa e raiz}

A maioria das plantas deste estrato, 59,67\%, não estava atrapalhando a passagem de pedestres e de veículos. As espécies que mais interferiam no trânsito eram as falsas-murtas, as aroeiras-salsas, as figueiras benjamim, os resedás e os oitis.

Dos cinco estratos estudados, este teve a maior quantidade de plantas classificadas como tendo copa com aspecto atípico, alcançando 13,99\%; este dado tem relação com a elevada incidência de plantas podadas encontrada para este estrato (conforme será visto adiante). Estavam com aspecto de copa razoável $29,42 \%$ das plantas e $56,58 \%$ tinham copa com aspecto típico.

Quanto à variável raiz, verificou-se que $5,56 \%$ do total de plantas possuíam raízes que estavam danificando a calçada (classe 1), 22,22\% possuíam raízes que estavam começando a danificar a calçada (classe 2) e $72,22 \%$ delas possuíam raízes que não estavam danificando a calçada (classe 3). No total de plantas sem causar danos às calçadas estão agregadas as mudas, as plantas em estágio jovem e as plantas de pequeno porte, além disso, este alto valor está relacionado com a variável área livre, cuja porcentagem de "boa área livre" também foi elevada.

\subsubsection{Variáveis porte, área livre, obstáculo, tutor e fio}

Foram consideradas adequadas para o local onde estavam plantadas $55,76 \%$ das plantas, $12,14 \%$ foram consideradas parcialmente adequadas para o local e $32,10 \%$ foram consideradas inadequadas, contribuindo para isto as espécies magnólia amarela, aroeira-salsa, figueira benjamim, sibipiruna e jambolão.

Tinham pouquíssima ou nenhuma área livre ao redor do tronco (classe 1) $18,93 \%$ das plantas, $48,97 \%$ tinham uma pequena área livre ao redor do tronco (classe 2 ) e 32,10\% tinham uma boa área livre (classe 3 ). Nota-se que o estrato azul teve a segunda maior porcentagem de boa área livre, talvez pela influência do fator sócio-econômico, já que as residências neste estrato têm uma extensão de calçada, em geral, maior que a de 
outros estratos, permitindo deixar um espaço maior para as covas, além de ser comum encontrar áreas gramadas ao redor das mesmas.

Das plantas vivas, 96,09\% não estavam próximas a obstáculo que pudesse atrapalhar seu desenvolvimento. Os dois obstáculos que apareceram com maior freqüencia foram poste, em $2,88 \%$ dos casos, e encanamento, em $0,62 \%$ dos casos.

Das 486 plantas deste estrato, 62 ou 12,76\% tinham um tutor auxiliando no crescimento.

Mais da metade do total de plantas vivas, ou seja, 57\% foram plantadas sob a fiação. Analisando as plantas mortas mais as covas abertas, verificou-se que do total de 93 elementos, $64,52 \%$ estavam debaixo de fios.

\subsubsection{Variáveis muda, frutífera, íntegra, poda, doença, praga, morta e cova}

O estrato azul teve a maior quantidade de mudas entre os cinco estratos, com valor correspondente a $9,26 \%$.

As quatro espécies frutíferas encontradas - goiabeira, mangueira, abacateiro e amoreira - representaram $2,06 \%$ do total de plantas.

Eram integras $68,93 \%$ das plantas deste estrato. A quantidade de plantas com problema de poda - $24,69 \%$ - ficou bem acima do valor encontrado nos outros estratos, sendo $12,76 \%$ devido à prática de poda drástica, 9,46\% por falta de poda de condução, 1,44\% estavam rebrotando depois de terem sido cortadas e $1,03 \%$ sofreram poda mal feita. Doença foi problema para $4,94 \%$ das plantas e praga para $6,79 \%$.

O número de plantas mortas foi de 47 ou $8,12 \%$ do total de elementos analisados neste estrato. As covas abertas mas sem plantas ocorreu com uma freqüencia de $7,94 \%$. 


\subsubsection{Estrato verde}

\subsubsection{Variáveis comprimento de quadra, largura de rua, tipo de ocupação e largura de calçada}

O valor médio de comprimentro de quadra calculado para o estrato verde foi de 102,19 metros, com uma variação de 10 a 250 metros; 27,4\% das quadras possuíam 90 metros de comprimento, $8,2 \%$ possuíam 60 metros e $4,3 \%$ possuíam 140 metros.

A largura média das ruas foi de 8,56 metros e a das calçadas foi de 2,28 metros.

Eram ocupadas com residências $78,1 \%$ das quadras; este estrato teve a maior porcentagem de quadras ocupadas com comércio - 13,7\% - pois abrange o Centro e a menor porcentagem de quadras ainda sem ocupação - 2,7\%. Do restante das quadras, $3,4 \%$ tinham indústria e $2,1 \%$ tinham escola.

\subsubsection{Variável espécie}

O número de elementos analisados no estrato verde foi de 490 ou $18,19 \%$ do total de elementos de todos os estratos.

O número de plantas vivas foi de 401, abrangendo 43 espécies diferentes. Dessas 43 espécies catalogadas, 19 ou 44,19\% estavam representadas com apenas um indivíduo. As cinco espécies mais freqüentes deste estrato (tabela 6) foram as mesmas encontradas no estrato azul, porém em ordem diferente.

Tabela 6 - Espécies analisadas no estrato verde com mais de 14 indivíduos: nome científico, nome vulgar, freqüência e porcentagem.

\begin{tabular}{lccc}
\hline Nome científico & Nome vulgar & Freqüência & Porcentagem \\
\hline Michelia champaca L. & magnólia amarela & 74 & 18,45
\end{tabular}


Tabela 6 - Espécies analisadas no estrato verde com mais de 14 indivíduos: nome científico, nome vulgar, freqüência e porcentagem.

\begin{tabular}{llcc}
\hline Nome científico & Nome vulgar & Freqüência & Porcentagem \\
\hline Murraya paniculata Jack. & falsa-murta & 54 & 13,47 \\
Caesalpinia peltophoroides Benth. & sibipiruna & 46 & 11,47 \\
Schinus molle L. & aroeira-salsa, cha- & 41 & 10,22 \\
& péu mexicano & & \\
Bauhinia variegata L. & pata-de-vaca & 37 & 9,23 \\
Tabebuia chrysotricha (Mart. Ex & ipê-amarelo & 26 & 6,48 \\
DC.)Standl. & & & \\
Ficus benjamina L. & figueira benjamim & 22 & 5,49 \\
Nectondra megapotamica (Spreng.) & canelinha & 16 & 3,99 \\
Mez & & 14 & 3,49 \\
Syagrus romanzoffiana (Cham.) & jerivá & & \\
Glassman & & & \\
\hline
\end{tabular}

\subsubsection{Variáveis altura e DAP}

Das plantas vivas deste estrato, 43,39\% tinham até 4,50 metros de altura (classe 1), 49,88\% tinham entre 4,50 e 8,20 metros de altura (classe 2) e 6,73\% tinham mais de 8,20 metros de altura (classe 3 ).

O maior valor de DAP encontrado foi 66,85 centímetros, o menor foi 0,16 e o valor médio foi 17,66 . Vinte e sete plantas não tinham atingido 1,30 metros de altura no momento da medição.

Como este estrato abrange o Centro, área mais antiga da cidade, observa-se, tanto pelo DAP médio quanto pela quantidade de plantas acima de 8,20 metros de altura, que as plantas nele presentes são maiores que as dos outros estratos. 


\subsubsection{Variáveis bifurcação, copa e raiz}

O número de plantas que não atrapalhavam a passagem de pedestres e de veículos, $68,83 \%$, foi o maior dos cinco estratos, mais um sinal de que as plantas do estrato verde são mais antigas.

Para a variável copa das plantas o resultado obtido foi o seguinte: $9,48 \%$ das plantas foram classificadas como tendo copa com aspecto atípico (classe 1), 27,93\% com aspecto razoável (classe 2) e 62,59\% com aspecto típico (classe 3 ).

Quanto à variável raiz, averiguou-se que 6,76\% das plantas tinham raizes que estavam danificando a calçada e $26,43 \%$ delas estavam começando a danificar, principalmente pela presença de magnólias amarelas e sibipirunas; $66,83 \%$ das plantas não danificavam a calçada.

\subsubsection{Variáveis porte, área livre, obstáculo, tutor e fio}

Para a variável porte das plantas os resultados mostram que $34,16 \%$ do total de plantas eram inadequadas para o local do plantio (classe 1), 12,97\% eram parcialmente adequadas para o local (classe 2) e 52,87\% eram adequadas para o local (classe 3). Foi o menor valor de plantas adequadas ao local do plantio comparado aos outros estratos, devido sobretudo à presença de árvores de grande porte em região de intensa circulação de veículos e pedestres.

Pouquíssima ou nenhuma área livre ao redor do tronco (classe 1) foi encontrada em $30,42 \%$ das plantas, uma pequena área livre ao redor do tronco (classe 2 ) foi encontrada em $55,86 \%$ das plantas e uma boa área livre (classe 3 ) foi encontrada em $13,72 \%$ das plantas.

Mais uma vez o estrato verde teve um valor que ficou abaixo do anotado nos outros estratos: o de boa área livre ao redor do tronco. Isto em razão da predominância de quadras em área comercial, local onde a árvore não tem a mesma importância que as vitrines de uma loja ou que as placas mostrando promoções. 
Os obstáculos que atrapalhavam o desenvolvimento das plantas ou poderiam servir de justificativa para o corte das mesmas foram para 3,99\% delas um poste, para $1,25 \%$ uma outra planta e para 1,00\% a marquise sobre elas. Outros obstáculos foram: garagem, placa de trânsito, encanamento, suporte de lixo e bueiro. Estavam livres de obstáculo $92,52 \%$ das plantas.

Das 401 plantas deste estrato, $12,22 \%$ tinham um tutor auxiliando no crescimento.

A maioria das plantas vivas, 57,61\%, estavam debaixo da fiação. Quanto às plantas mortas e covas abertas, verificou-se que $62,92 \%$ estavam sob fios.

\subsubsection{Variáveis muda, frutífera, integra, poda, doença, praga, morta e cova}

Neste estrato foi encontrado um valor de mudas correspondente a 6,23\% do total de plantas.

As fiutíferas somaram $1,25 \%$ das plantas levantadas, valor distribuído entre as plantas mangueira, limoeiro e amoreira.

Estavam integras $72,82 \%$ de todas as plantas, $16,71 \%$ tiveram problemas com poda $(8,98 \%$ com poda drástica, $4,24 \%$ sem poda de condução, $2,74 \%$ estavam rebrotando e 0,75\% com poda mal feita), 4,74\% apresentavam doença e 8,23\% estavam com praga, sendo este último o valor mais alto obtido entre os cinco estratos.

Dos 490 elementos deste estrato 53 eram plantas mortas e 36 eram covas abertas, correspondendo a $10,82 \%$ e $7,35 \%$ do total de elementos do estrato, respectivamente. Também o número de árvores mortas foi o mais elevado entre os estratos, que associado ao alto índice de plantas com praga, aponta a região contida no estrato verde como a mais estressante para as plantas. 


\subsubsection{Estrato amarelo}

\subsubsection{Variáveis comprimento de quadra, largura de rua, tipo de ocupação e largura de calçada}

O comprimento médio das quadras do estrato amarelo foi o maior calculado entre os cinco estratos, 121,03 metros. A extensão das quadras variou de 20 a 720 metros, sendo que $16,5 \%$ do total de quadras tinham 60 metros de comprimento, $14,4 \%$ tinham 90 metros e 10,1\% tinham 100 metros de comprimento.

A largura das ruas medidas no estrato amarelo teve um valor médio igual a 8,27 metros; o estrato com maior média de comprimento de quadra teve a menor largura média das calçadas, que foi de 2,17 metros.

A maioria das quadras, perfazendo $75,5 \%$, eram ocupadas com residências, $10,8 \%$ das quadras eram ocupadas com comércio, $6,5 \%$ com indústria, 4,4\% das quadras foram classificadas como indefinidas (ainda sem ocupação), 1,4\% eram de lazer, $0,7 \%$ possuía escola e $0,7 \%$ era ocupada com prestação de serviços.

\subsubsection{Variável espécie}

O total de elementos levantados neste estrato foi de 441 ou $16,37 \%$ do total de elementos dos cinco estratos.

Dos elementos medidos, 374 eram plantas vivas pertencentes a 42 espécies diferentes, das quais dezesseis $(38,1 \%)$ figuraram com apenas um indivíduo.

Este foi o único estrato que não teve a aroeira-salsa entre as cinco espécies mais freqüentes, conforme mostra a tabela 7 . 
Tabela 7 - Espécies analisadas no estrato amarelo com mais de 14 indivíduos: nome científico, nome vulgar, freqüência e porcentagem.

\begin{tabular}{|c|c|c|c|}
\hline Nome científico & Nome vulgar & Freqüência & Porcentagem \\
\hline Michelia champaca $\mathrm{L}$. & magnólia amarela & 70 & 18,72 \\
\hline Murraya paniculata Jack. & falsa-murta & 63 & 16,84 \\
\hline Caesalpinia peltophoroides Benth. & sibipiruna & 40 & 10,70 \\
\hline Ficus benjamina $\mathrm{L}$. & figueira benjamim & 25 & 6,68 \\
\hline Bauhinia variegata $\mathrm{L}$. & pata-de-vaca & 23 & 6,15 \\
\hline Nectandra megapotamica (Spreng.) & canelinha & 19 & 5,08 \\
\hline \multicolumn{4}{|l|}{ Mez } \\
\hline Terminalia catappa L. & $\begin{array}{l}\text { sete copas, chapéu- } \\
\text {-de-sol }\end{array}$ & 18 & 4,81 \\
\hline Ligustrum lucidum Ait. & alfeneiro & 16 & 4,28 \\
\hline Eugenia jambolana Lam. & jambolão & 15 & 4,01 \\
\hline Schinus molle $\mathrm{L}$. & $\begin{array}{l}\text { aroeira-salsa, cha- } \\
\text { péu mexicano }\end{array}$ & 14 & 3,74 \\
\hline
\end{tabular}

\subsubsection{Variáveis altura e DAP}

Do total de plantas deste estrato, 47,06\% tinham até 4,50 metros de altura (classe 1), 48,93\% tinham entre 4,50 e 8,20 metros de altura (classe 2) e 4,01\% tinham mais de 8,20 metros de altura (classe 3).

O DAP médio das árvores deste estrato foi de 16,86 centímetros, sendo 0,16 centímetros o menor DAP medido e 63,03 o maior. Dezessete plantas não tinham atingido 1,30 metros de altura na ocasião do levantamento. 


\subsubsection{Variáveis bifurcação, copa e raiz}

A quantidade de plantas que não estavam atrapalhando a passagem de pedestres e de veículos somou $61,23 \%$.

Foram classificadas como tendo copa com aspecto atípico (classe 1) 9,63\% das plantas, $27,54 \%$ tinham aspecto razoável (classe 2), e 62,83\% tinham aspecto típico (classe 3). A espécie com a maioria dos indivíduos na classe 1 foi o alfeneiro, com indivíduos na classe 2 foi a pata-de-vaca e com indivíduos na classe 3 foi a falsa-murta.

As plantas com raízes danificando a calçada foram $6,68 \%$ do total, $24,33 \%$ do total estavam começando a danificar e 68,98\% não danificavam a calçada.

\subsubsection{Variáveis porte, área livre, obstáculo, tutor e fio}

Para a variável porte das árvores viu-se que $31,02 \%$ do total de plantas eram inadequadas para o local (classe 1), 12,83\% eram parcialmente adequadas (classe 2 ) e $56,15 \%$ eram adequadas para o local (classe 3 ). As espécies com maior porcentagem de árvores inadequadas para o local de plantio foram figueira benjamim, chapéu-de-sol e pata-de-vaca.

A porcentagem de plantas com pouquíssima ou nenhuma área livre ao redor do tronco (classe 1) foi igual a $31,02 \%, 54,01 \%$ das plantas tinham uma pequena área livre ao redor do tronco (classe 2) e 14,97\% das plantas tinham uma boa área livre (classe 3).

Não tinham obstáculo ao redor 354 plantas ou $94,65 \%$ do total; $3,21 \%$ das plantas estavam próximas a um poste, 0,80\% estavam próximas ao encanamento, $0,53 \%$ a uma garagem, $0,27 \%$ estava próxima à esquina, $0,27 \%$ estava debaixo de uma marquise e $0,27 \%$ estava rodeada de entulho.

Das 374 plantas vivas deste estrato, 7,49\% tinham um tutor auxiliando no crescimento. 
Um pouco mais da metade das plantas, $56,15 \%$, estava debaixo da fiação. Das 67 plantas mortas e covas abertas, 53,73\% localizavam-se debaixo de fios.

\subsubsection{Variáveis muda, frutífera, íntegra, poda, doença, praga, morta e cova}

Plantas que eram mudas representaram $6,95 \%$ do total medido neste estrato.

Limoeiro, mangueira, jabuticabeira, goiabeira e uvaieira foram as frutíferas encontradas e que somaram $1,60 \%$ do total de plantas analisadas no estrato amarelo.

Plantas integras corresponderam a $75,67 \%$ do total de plantas. Este estrato teve o segundo valor mais alto de plantas com problema de poda, 19,25\%, dividido da seguinte forma: $9,09 \%$ das plantas tiveram poda drástica, 5,61\% não tiveram poda de condução, $2,94 \%$ eram rebrota e $1,60 \%$ sofreram poda mal feita.

Doença foi problema para $2,67 \%$ das plantas e $3,74 \%$ das plantas estavam com praga.

O número de plantas mortas foi de 38 ou $8,62 \%$ do total de elementos do estrato e o número de covas foi de 29 ou $6,58 \%$.

\subsubsection{Estrato laranja}

\subsubsection{Variáveis comprimento de quadra, largura de rua, tipo de ocupação e largura de calçada}

O estrato laranja teve o menor comprimento médio das quadras - 94,13 metros - sendo que $17,3 \%$ do total de quadras tinham 60 metros de comprimento, $15,7 \%$ tinham 90 metros e 10,2\% tinham 100 metros de comprimento.

$\mathrm{O}$ valor médio da largura das ruas amostradas neste estrato foi de 8,15 metros e o das calçadas foi de 2,34 metros. 
As quadras ocupadas com residências somaram $76,2 \%, 11,0 \%$ do total eram comércio, 5,5\% eram escola, $2,4 \%$ ainda não estavam ocupadas e $1,6 \%$ era indústria. Aqui encontrou-se a maior porcentagem de quadras com escola, local propício para incrementar a arborização por poder envolver os alunos nas atividades de plantio e manutenção das árvores, educando-os para melhorar o ambiente no qual passam boa parte de suas vidas.

\subsubsection{Variável espécie}

O número de elementos analisados no estrato laranja foi de 393 ou $14,59 \%$ do total de elementos de todos os estratos.

O total de plantas vivas foi de 336 agrupadas em 37 diferentes espécies. Dezenove espécies, $51,35 \%$, tinham apenas um indivíduo. Na tabela 8 estão as espécies amostradas neste estrato, que foi o único que não apresentou a sibipiruna entre as cinco espécies mais freqüentes.

Tabela 8 - Espécies analisadas no estrato laranja com mais de 14 indivíduos: nome científico, nome vulgar, freqüência e porcentagem.

\begin{tabular}{llcc}
\hline Nome científico & Nome vulgar & Freqüência & Porcentagem \\
\hline Michelia champaca L. & magnólia amarela & 88 & 26,19 \\
Murraya paniculata Jack. & falsa-murta & 75 & 22,32 \\
Ligustrum lucidum Ait. & alfeneiro & 32 & 9,52 \\
Schinus molle L. & aroeira-salsa, cha- & 25 & 7,44 \\
& péu mexicano & & \\
Ficus benjamina L. & figueira benjamim & 21 & 6,25 \\
Nectandra megapotamica (Spreng.) & canelinha & 17 & 5,06 \\
Mez & & & \\
Caesalpinia peltophoroides Benth. & sibipiruna & 14 & 4,17 \\
\hline
\end{tabular}


As duas primeiras espécies listadas na tabela 8 estão com as porcentagens mais altas encontradas entre os cinco estratos e ultrapassam largamente a freqüência de $10 \%$ já mencionada como sendo a ideal para cada espécie. Outro fator preocupante neste estrato é a alta freqüência de figueira benjamim, árvore de porte grande que costuma causar muitos danos tanto à calcada como ao encanamento, chegando inclusive a ser proibida por lei de ser plantada nas calçadas de algumas cidades, como por exemplo em Piracicaba (Lima, 1993).

\subsubsection{Variáveis altura e DAP}

Para a variável altura viu-se que $53,87 \%$ das plantas deste estrato tinham até 4,50 metros de altura (classe 1), 43,45\% tinham entre 4,50 e 8,20 metros (classe 2) e $2,68 \%$ tinham mais de 8,20 metros de altura (classe 3 ).

O menor DAP medido foi 0,32 centímetros, o maior foi 76,08 e o valor médio foi 12,89 centímetros. Vinte plantas tiveram o valor de DAP igual a zero por estarem abaixo de 1,30 metros de altura no momento da medição.

\subsubsection{Variáveis bifurcação, copa e raiz}

O valor de plantas que não estavam atrapalhando a passagem de pesdestres e de veículos neste estrato atingiu $61,31 \%$.

Dos cinco estratos, este teve a porcentagem mais baixa de plantas tendo copa com aspecto atípico, $7,14 \%$ do total; $22,92 \%$ tinham aspecto razoável e $69,94 \%$ com aspecto típico.

Das plantas vivas, 2,68\% tinham raízes que danificavam a calçada, 19,94\% estavam começando a danificar e $77,38 \%$ não danificavam a calçada. 


\subsubsection{Variáveis porte, área livre, obstáculo, tutor e fio}

Os resultados encontrados para a variável porte das plantas mostram que $32,44 \%$ do total de plantas eram inadequadas para o local, $11,01 \%$ eram parcialmente adequadas para o local e 56,55\% eram adequadas para o local do plantio.

Plantas com pouquíssima ou nenhuma área livre ao redor do tronco foram $27,68 \%$ do total amostrado; $58,04 \%$ das plantas tinham uma pequena área livre ao redor do tronco e $14,29 \%$ das plantas tinham uma boa área livre.

Os três obstáculos mais freqüentes foram o poste (para 2,38\% dos casos), seguido pela marquise ( $1,49 \%$ dos casos) e pela placa de trânsito ( $1,19 \%$ dos casos). Não estavam próximas a obstáculo $91,96 \%$ das plantas.

Das 336 plantas do estrato laranja, 37 ou 11,01\% tinham um tutor auxiliando no crescimento.

Mais da metade das plantas vivas, $57,14 \%$, estavam debaixo da fiação. Considerando-se somente as plantas mortas e as covas, verificou-se que $50,88 \%$ delas estavam sob fios.

\subsubsection{Variáveis muda, frutífera, integra, poda, doença, praga, morta e cova}

As mudas constituiram $6,85 \%$ do total de plantas amostradas no estrato laranja.

Apenas $0,89 \%$ das plantas, menor porcentagem de todos os estratos, eram frutiferas. As frutiferas registradas foram mangueira, abacateiro e jaqueira.

Estavam integras $83,63 \%$ das plantas do estrato laranja.

Mas tiveram problemas com poda $13,10 \%$ das plantas, sendo $7,74 \%$ por poda drástica, $2,98 \%$ por falta de poda de condução, $1,19 \%$ por ser rebrota e $1,19 \%$ por poda mal realizada. 
Tinham problema de doença $2,08 \%$ das plantas. Com praga, estavam $2,08 \%$ das plantas.

Foram encontradas 30 plantas mortas e 27 covas, o que representou $7,63 \%$ e $6,87 \%$ do total de elementos do estrato, respectivamente.

\subsubsection{Estrato vermelho}

\subsubsection{Variáveis comprimento de quadra, largura de rua, tipo de ocupação e largura de calçada}

$\mathrm{O}$ estrato vermelho teve para a variável comprimento das quadras um valor médio de 110,37 metros. Do total de 270 quadras amostradas, 7,0\% tinham 40 metros de comprimento, 19,6\% tinham 50 metros e 8,9\% tinham 200 metros. Neste estrato foi encontrada a maior variação de extensão de quadras, desde 20 até 950 metros, dado que sugere uma falta de planejamento nos loteamentos mais recentes.

A média da largura das ruas foi de 8,02 metros e a média da largura das calçadas foi de 2,22 metros.

Dos cinco estratos, este teve o maior índice de quadras desocupadas (ou indefinidas), chegando a $19,6 \%$. A porcentagem de quadras com residências foi $72,2 \%$, com comércio foi $5,6 \%$, com escola foi $1,1 \%$, com indústria também foi $1,1 \%$ e em apenas uma quadra $(0,4 \%)$ predominou ocupação destinada ao lazer.

\subsubsection{Variável espécie}

O total de elementos amostrados no estrato vermelho, 791, representou $29,36 \%$ do total de elementos de todos os estratos.

O total de plantas vivas foi de 657 , com 63 espécies diferentes, porém deste total, 28 espécies $(44,44 \%)$ tinham apenas um indivíduo. Na tabela 9 estão as 14 espécies mais freqüentes deste estrato. 
Tabela 9 - Espécies analisadas no estrato vermelho com mais de 14 indivíduos: nome científico, nome vulgar, freqüência e porcentagem.

\begin{tabular}{llcc}
\hline Nome científico & Nome vulgar & Freqüência & Porcentagem \\
\hline Michelia champaca L. & magnólia amarela & 142 & 21,61 \\
Murraya paniculata Jack. & falsa-murta & 142 & 21,61 \\
Schinus molle L. & aroeira-salsa, cha- & 74 & 11,26 \\
& péu mexicano & & \\
Ficus benjamina L. & figueira benjamim & 52 & 7,91 \\
Caesalpinia peltophoroides Benth. & sibipiruna & 28 & 4,26 \\
Ligustrum lucidum Ait. & alfeneiro & 27 & 4,11 \\
Licania tomentosa (Benth.) & oiti & 20 & 3,04 \\
Fritsch. & & & \\
Bauhinia variegata L. & pata-de-vaca & 19 & 2,89 \\
Terminalia catappa L. & sete copas, chapéu- & 18 & 2,74 \\
& -de-sol & & \\
\hline
\end{tabular}

Novamente vê-se que a freqüência das duas primeiras colocadas está além da recomendável e que a espécie figueira benjamim aparece com uma freqüência bem elevada, podendo exigir, brevemente, atividade de poda para contenção do tamanho da árvore.

\subsubsection{Variáveis altura e DAP}

Tinham até 4,50 metros de altura $67,88 \%$ das plantas deste estrato, $30,59 \%$ tinham entre 4,50 e 8,20 metros de altura e apenas $1,52 \%$ tinham mais de 8,20 metros de altura. Pelo último dado conclui-se que as plantas do estrato vermelho ainda são jovens e que muitas poderão causar transtornos, visto que todas as espécies com mais de 14 exemplares, com exceção da falsa-murta, são de médio a grande porte. 
O menor DAP medido foi 0,32 centímetros, o maior foi $70,03 \mathrm{~cm}$ e o DAP médio foi o menor dos cinco estratos, $10,97 \mathrm{~cm}$. Não foram calculados o DAP de 101 plantas, pois não tinham alcançado 1,30 metros de altura por ocasião do levantamento dos dados.

\subsubsection{Variáveis bifurcação, copa e raiz}

Neste estrato encontrou-se a menor porcentagem de plantas atrapalhando a passagem de pesdestres e de veículos, $56,32 \%$.

Copa com aspecto atípico foi encontrada em $9,13 \%$ das plantas deste estrato, $26,03 \%$ das plantas tinham copa com aspecto razoável e $64,84 \%$ com aspecto típico.

Em conseqüência do elevado número de plantas jovens e pelo fato de muitas calçadas deste estrato ainda não terem recebido pavimentação, encontrou-se a maior porcentagem de plantas com raizes que não danificavam a calçada, $84,17 \%$; $13,85 \%$ das plantas tinham raizes que estavam começando a danificar o calçamento e $1,98 \%$ das plantas tinham raizes que danificavam a calçada.

\subsubsection{Variáveis porte, área livre, obstáculo, tutor e fio}

Eram inadequadas para o local do plantio $25,88 \%$ do total de plantas, $13,24 \%$ eram parcialmente adequadas para o local e $60,88 \%$ eram adequadas para o local do plantio.

Pouquíssima ou nenhuma área livre ao redor do tronco foi encontrada em $12,94 \%$ das plantas, uma pequena área livre ao redor do tronco foi encontrada em $49,01 \%$ das plantas e uma boa área livre foi encontrada em $38,05 \%$ das plantas, exatemente pelo fato de muitas calçadas não terem recebido pavimentação.

Não estavam perto de obstáculos $95,13 \%$ das plantas. Os obstáculos mais freqüentes foram em $1,22 \%$ das vezes uma outra planta na mesma cova, em $0,76 \%$ das 
vezes havia entulho ao redor da planta e em $0,91 \%$ a planta estava a menos de 5 metros de um poste; outros obstáculos anotados foram garagem, encanamento, suporte de lixo, marquise, orelhão, placa e bueiro. Este estrato engloba muitos bairros recentes, com grande quantidade de residências sendo construídas e consequentemente com grande quantidade de sobras de material, que, por desleixo dos moradores e da administração municipal, acabam ficando na frente das casas, em geral perto da árvore existente na calçada.

Das 657 plantas deste estrato, 100 ou 15,22\% tinham um tutor auxiliando no crescimento.

Encontravam-se debaixo da fiação 57,61\% das plantas vivas. Quanto às plantas mortas e covas abertas, $61,94 \%$ estavam debaixo de fios.

\subsubsection{Variáveis muda, frutífera, íntegra, poda, doença, praga, morta e cova}

Do total de plantas do estrato vermelho, $6,23 \%$ eram mudas.

As frutiferas tiveram neste estrato a maior porcentagem no total de plantas, que foi de 3,2\%. A grande variedade de frutíferas, tais como amexeira, pitangueira, mangueira, limoeiro, abacateiro, goiabeira, mamoeiro, tamarindeiro, ateira e jatobá, mostra que há muita influência da população no plantio e na escolha das espécies presentes nas calçadas deste estrato.

Encontrou-se no estrato vermelho a maior porcentagem de plantas integras, 86,45\%, mais um indicativo de plantas jovens, que ainda não sofreram interferências. Poda foi problema para $11,57 \%$ das plantas, assim subdividida: 5,94\% sem poda de condução, $3,04 \%$ de poda drástica, $2,13 \%$ de rebrota e $0,46 \%$ de poda mal feita; $1,52 \%$ das plantas apresentaram doença e apenas 1,06\% tinham praga.

Foram encontradas 72 plantas mortas neste estrato ou $9,10 \%$ do total de elementos e 62 ou $7,84 \%$ de todos os elementos eram covas abertas. 
A tabela 10 mostra os resultados de algumas variáveis analisadas na amostragem estratificada, dispostos de maneira a permitir uma melhor comparação entre os valores encontrados para os cinco estratos. 


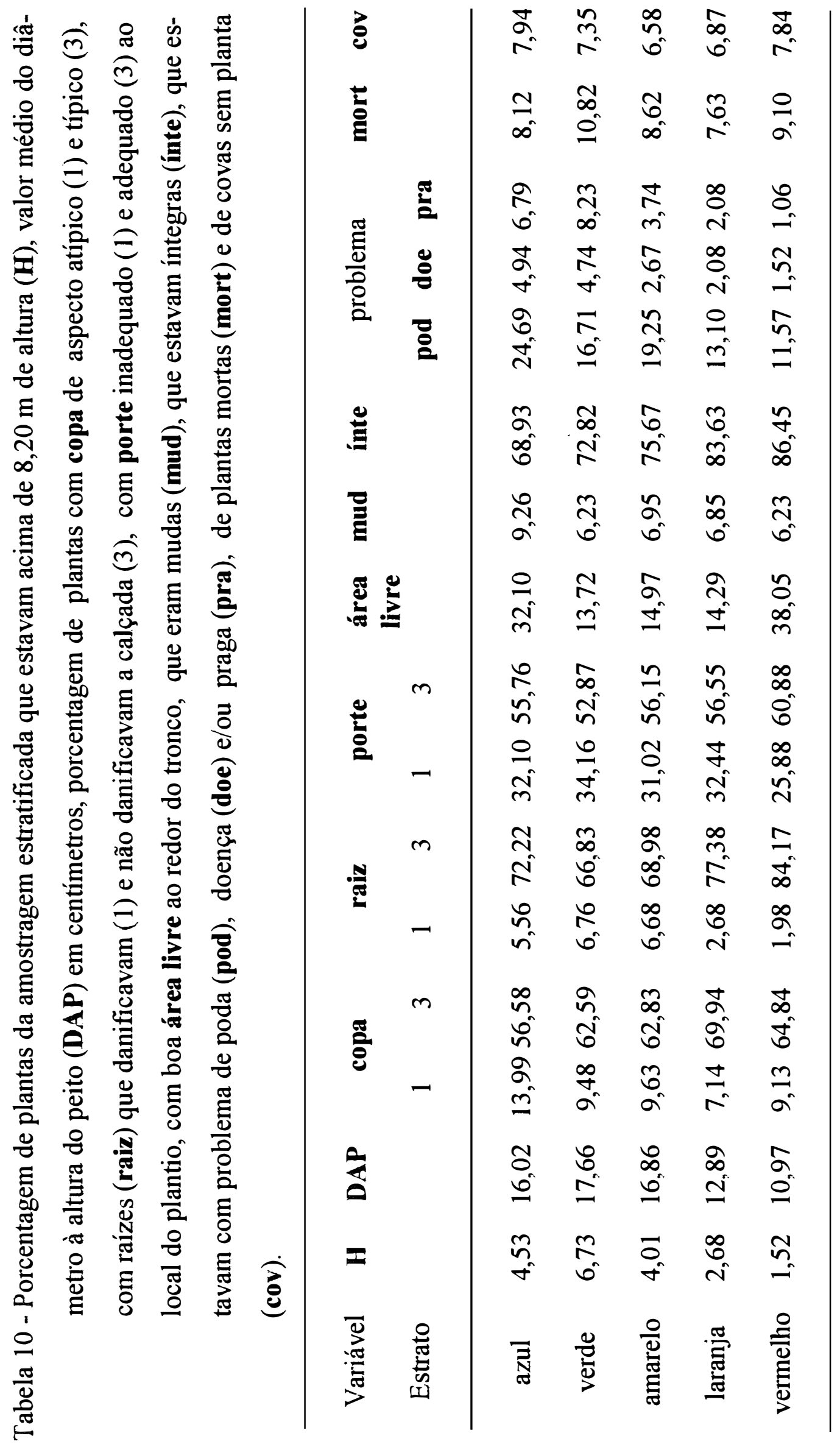




\section{CONCLUSÕES}

1. As duas metodologias - amostragem casual simples e amostragem estratificada foram apropriadas para o levantamento de árvores de rua na cidade de São Carlos. Porém, recomenda-se o emprego da amostragem casual simples, visto que o ganho em precisão obtido com a amostragem estratificada por nivel sócio-econômico foi muito pequeno, não compensando o trabalho para sua elaboração.

2. As metodologias apresentadas neste trabalho não exigem que as unidades de amostragem sejam do mesmo tamanho, são aplicadas diretamente nos quarteirões, independentemente de suas dimensões. Também prescindem de informação sobre a quantidade de árvores existentes nas unidades amostrais e são empregadas sem censurar as unidades com baixo índice de arborização.

3. As duas variáveis usadas para quantificar a abundância de árvores de rua foram eficientes, mas, para efeito de comparação e por ser de manuseio mais simples, recomenda-se o uso da variável "número de árvores por quilômetro de calçada".

4. Devem ser excluídos do sistema de referência aqueles quarteirões destinados exclusivamente às áreas verdes.

5. A relação entre o indice de arborização e o tipo de ocupação das quadras verificada nos estratos verde (menor porcentagem de quadras sem árvores e de quadras desocupadas) e vermelho (maior porcentagem de quadras sem árvores e de quadras 
desocupadas) sugere como variável de estratificação a ser empregada em um próximo trabalho a "densidade de ocupação" dos bairros.

6. O número de árvores por quilômetro de calçada obtido com a amostragem casual simples foi de 30,12, dado que permite estimar para a cidade de São Carlos um total de elementos (incluindo plantas vivas, plantas mortas e covas abertas) variando entre 28.556 e 34.595 .

7. Dos 2.958 elementos medidos pela amostragem casual simples, 2.461 eram árvores, arbustos e plantas herbáceas, 265 eram covas abertas mas sem plantas e 232 eram plantas mortas. As cinco espécies mais freqüentes foram Michelia champaca (24,95\%), Murraya paniculata (12,68\%), Schinus molle (9,47\%), Caesalpinia peltophoroides $(6,30 \%)$ e Bauhinia variegata $(6,30 \%)$. As duas primeiras espécies apareceram com uma freqüência acima do recomendável e devem ser evitadas nos próximos plantios.

8. O DAP médio obtido para as plantas da amostragem casual simples foi de 13,67 centímetros e apenas $2,52 \%$ do total ultrapassavam 8,20 metros de altura, dados que mostram que os exemplares de muitas espécies ainda não atingiram a maturidade.

9. Das plantas amostradas pelo método casual simples, $40,15 \%$ atrapalhavam a passagem de pedestres, 59,81\% tinham a copa com aspecto sadio, 72,65\% tinham raízes que ainda não danificavam a calçada, 52,62\% eram adequadas para o local onde estavam plantadas e $72,61 \%$ das plantas eram sadias. Foram altos os índices de elementos debaixo de fiação, $53,75 \%$, e de plantas com pequena área livre ao redor do tronco, $46,52 \%$.

10. Michelia champaca (magnólia amarela) e Murraya paniculata (falsa-murta) foram as espécies que apareceram com maior freqüência também para cada um dos cinco estratos. 
11. O estrato azul foi o que apresentou a maior porcentagem de plantas com copa de aspecto atípico, em grande parte por ter sido alta a quantidade de plantas com problemas de poda, num total de $24,69 \%$.

12. Por abranger o Centro, região mais antiga da cidade, o estrato verde teve a maior quantidade de quadras comerciais , $13,7 \%$, a maior porcentagem de plantas com porte adulto - maior média de DAP (17,66 centímetros) e maior porcentagem de plantas acima de 8,20 metros de altura $(6,73 \%)$ - e a maior quantidade de plantas mortas, $10,82 \%$.

13. O estrato amarelo teve a maior média de comprimento de quadras calculada entre os cinco estratos, 121,03 metros, e a menor largura média das calçadas, 2,17 metros. Foi também o segundo estrato a apresentar a maior porcentagem de plantas com problemas de poda, $19,25 \%$.

14. O estrato laranja foi o que apresentou a maior porcentagem de quadras ocupadas com escolas, 5,5\%, local ideal para receber uma incrementação da arborização, envolvendo os alunos em atividades de educação ambiental. Nele encontrou-se a menor porcentagem de plantas com copa atípica, 7,14\%, e de plantas frutíferas, $0,89 \%$.

15. No estrato vermelho apurou-se a maior quantidade de plantas jovens - menor DAP médio (10,97 centímetros) e menor porcentagem de plantas com mais de 8,20 metros de altura $(1,52 \%)$ - dados que associados ao fato de haver muitas calçadas ainda sem pavimentação, fez com que neste estrato existisse a maior quantidade de plantas sem causar danos ao calçamento $(84,17 \%)$ e com boa área livre ao redor do tronco $(38,05 \%)$. 


\section{REFERÊNCIAS BIBLIOGRÁFICAS}

ÁVILA, F.B. de. Pequena enciclopédia de moral e civismo. 3.ed. Rio de Janeiro: FENAME, 1978. 630p.

BASSET, J.R. Vegetation inventories: need and uses. In: NATIONAL URBAN FORESTRY CONFERENCE, Washington, 1978. Proceedings. Washington: USDA, Forest Service, 1978. v.2, p.632-644.

BIONDI, D. Diagnóstico da arborização de ruas da cidade do Recife. In: ENCONTRO NACIONAL SOBRE ARBORIZAÇÃO URBANA, 1., Porto Alegre, 1985. Anais. Porto Alegre: Secretaria Municipal do Meio Ambiente, 1985. p.87-88.

BRASIL, H.M.S.; BARROS, P.L C. de. Processo de amostragem utilizado para a caracterização da arborização de Belém - PA. In: CONGRESSO BRASILEIRO DE ARBORIZAÇÃO URBANA, 2; ENCONTRO NACIONAL SOBRE ARBORIZAÇÃO URBANA, 5, São Luís, 1994. Anais. p.181-191.

COCHRAN, W.G. Sampling thecniques. 3. ed. New York: John Wiley and Sons, 1977. $428 \mathrm{p}$.

COSTA, E.F.; KAMINSKI, N.L. Análise quali-quantitativa da arborização de ruas do Conjunto Habitacional "A" da Itaipu Binacional - Foz do Iguaçu - PR. In: ENCONTRO NACIONAL SOBRE ARBORIZAÇÃO URBANA, 3. Curitiba, 1990. Anais. p.252-262. 
COUTO, H.T.Z. do. Métodos de amostragem para avaliação de árvores de ruas. In: CONGRESSO BRASILEIRO DE ARBORIZAÇÃO URBANA, 2; ENCONTRO NACIONAL SOBRE ARBORIZAÇÃO URBANA, 5, São Luís, 1994. Anais. p. 169179.

DEMBNER, S. Urban forestry in Beijing. Unasylva, v.44, n.173, p.13-18, 1993.

GRAY, R.J.; JOHNSON, L.C.; CRAWFORD, C.E.C. The use of urban forest inventory information in the local land use planning process: National Urban Forest Inventory Project, Washington: Forest Policy Center, 1993. 88p.

HEISLER, G.M.; HERRINGTON, L.P. Seletion of trees for modifying metropolitan climates. In: Better trees for metropolitan landscapes - Symposium Proceedings: USDA, forest service general technical report NE-22, 1976. p.31-37.

KIRCHNER, F.F.; DETZEL, V.A.; MITISHITA, E.A. Mapeamento da vegetação urbana. In: ENCONTRO NACIONAL SOBRE ARBORIZAÇÃO URBANA, 3. Curitiba, 1990. Anais. p.72-85.

KUCHELMEISTER, G.; BRAATZ, S. Urban forestry revisited. Unasylva, v.44, n. 173, p.3-12, 1993.

LIMA, A.M.L.P. Piracicaba/SP: análise da arborização viária na área central e em seu entorno. Piracicaba, 1993. 238p. Tese (Doutorado) - Escola Superior de Agricultura 'Luiz de Queiroz", Universidade de São Paulo.

LIMA, P.C.F.; OLIVEIRA, V.R. de; NASCIMENTO, C.E. de S.; TORRES,S.B. Diagnóstico da arborização de ruas de Petrolina - PE. In: ENCONTRO NACIONAL SOBRE ARBORIZAÇÃO URBANA, 3. Curitiba, 1990. Anais. p.41-53. 
LOMBARDO, M.A. Vegetação e clima. In: ENCONTRO NACIONAL SOBRE ARBORIZAÇÃO URBANA, 3. Curitiba, 1990. Anais. p. 1-13.

LORANDI, R. Caracterização dos solos das áreas urbana e suburbana de São Carlos (SP) e suas aplicações. Piracicaba, 1985. 181 p. Tese (Doutorado) - Escola Superior de Agricultura 'Luiz de Queiroz", Universidade de São Paulo.

MALAVASI, U.C.; AGUIAR SOBRINHO, J.; GAMA, L.L.M.F. da; et al. A arborização urbana da cidade de Itaguai-RJ. Floresta e Ambiente, n.2, 1995, p.74-77.

MALINSKY, R. Arborização: uma visão integrada. In: ENCONTRO NACIONAL SOBRE ARBORIZAÇÃO URBANA, 1., Porto Alegre, 1985. Anais. Porto Alegre: Secretaria Municipal do Meio Ambiente, 1985. p.37-38.

MARTINS, S.V.; PAIVA, H.N. de; SOARES, C.P.B.; JACOVINE, L.A.G. Avaliação quali-quantitativa da arborização de ruas de Viçosa - MG. In: ENCONTRO NACIONAL SOBRE ARBORIZAÇÃO URBANA, IV, Vitória, 1992. Anais. p. 317-326.

McPHERSON, E.G. Using urban forests for energy efficiency and carbon storage. Journal of Forestry, v.92, n. 10, p.36-41, Oct. 1994.

MELLO FILHO, L.E. Arborização urbana. In: ENCONTRO NACIONAL SOBRE ARBORIZAÇÃO URBANA, 1., Porto Alegre, 1985. Anais. Porto Alegre: Secretaria Municipal do Meio Ambiente, 1985. p. 117-127.

MILANO, M.S. O planejamento da arborização, as necessidades de manejo e tratamentos culturais das árvores de ruas de Curitiba - PR. Revista Floresta, n. 17, p. 15-21, jun/dez. 1987. 
MILANO, M.S. Planejamento da arborização urbana: relações entre áreas verdes e ruas arborizadas. In: ENCONTRO NACIONAL SOBRE ARBORIZAÇÃO URBANA, 3. Curitiba, 1990. Anais. p.60-71.

MILANO, M.S. Métodos de amostragem para avaliação de arborização de ruas. In: CONGRESSO BRASILEIRO DE ARBORIZAÇÃO URBANA, 2; ENCONTRO NACIONAL SOBRE ARBORIZAÇÃO URBANA, 5, São Luís, 1994. Anais. p.163168.

MILANO, M.S.; SOARES, R.V. Aplicação de técnicas de amostragem aleatória para avaliação da arborização de ruas de Maringá - PR. In: ENCONTRO NACIONAL SOBRE ARBORIZAÇÃO URBANA, 3.Curitiba, 1990. Anais. p.244-251.

MILANO, M.S.; SARNOWSKI FILHO, O.; ROBAYO, J.A .M. Estudo comparativo de unidades amostrais utilizadas para inventário quali-quantitativo de arborização de ruas em Curitiba. In: ENCONTRO NACIONAL SOBRE ARBORIZAÇÃO URBANA, IV, Vitória, 1992. Anais. p.343-350.

MILLER, R.W. Urban forestry planning and managing urban greenspaces. Englewood Cliffs: Prentice Hall, 1988. cap.6, p.87-112: Street tree inventories.

MOLL, G. Improving the health of the urban forest. American Forests, v.93, n.11-12, p.61-64, Nov./Dec. 1987.

NOWAK, D.J. Understanding the struture of urban forests. Journal of Forestry. v.92, n. 10, p.42-46, Oct. 1994.

NUNES, M.L. Metodologias de avaliação da arborização urbana. In: ENCONTRO NACIONAL SOBRE ARBORIZAÇÃO URBANA, VI, Vitória, 1992. Anais. p.133- 
145.

OLIVEIRA, C.H. de. Planejamento ambiental na cidade de São Carlos (SP) com ênfase nas áreas públicas e áreas verdes: diagnóstico e propostas. São Carlos, 1996. 181p. Dissertação (Mestrado) - Universidade Federal de São Carlos.

PHILIPPI JR., A.; PELICIONI, M.C.F. Agenda 21 - o que, por que, para quê? Jornal da USP, São Paulo, 9 a 15 mar. 1998. p.2.

PROFOUS, G.; ROWNTREE, R. Structure and management of the urban forest in Prague. Unasylva, v.44, n.173, p.33-38, 1993.

REETHOF, G.; HEISLER, G.M. Trees and forests for noise abatement and visual screening. In: Better trees for metropolitan landscapes - Symposium Proceedings: USDA, forest service general technical report NE-22, 1976. p.39-47.

RYAN, J.J. Design considerations in the selection of cultivars for metropolitan higways. In: Better trees for metropolitan landscapes - Symposium Proceedings: USDA, forest service general technical report NE-22, 1976. p. 143-148.

SANTOS, N.R.Z. dos; TEIXEIRA, I.F. Levantamento quantitativo e qualitativo da arborização do bairro centro da cidade de Santa Maria - RS. In: ENCONTRO NACIONAL SOBRE ARBORIZAÇÃO URBANA, 3. Curitiba, 1990. Anais. p.263-268.

SANTOS, N.R.Z. dos; TEIXEIRA, I.F.; VACCARO, S. Avaliação qualitativa da arborização da cidade de Bento Gonçalves, RS. Ciência Florestal, v.1, n.1, p.88-99, 1991.

SIEVERT, R. Urban forestry - a municipal perspective. Journal of Forestry. v. 92 , n. 10, p.19-22, Oct. 1994. 
SOUSA, M.A. de L.B.; CONTE, A.M.; BARDELLI, G.; LATINI, M. Análise e caracterização da arborização viária da parte central da cidade de Botucatu - SP. In: ENCONTRO NACIONAL SOBRE ARBORIZAÇÃO URBANA, 3. Curitiba, 1990. Anais. p.236-243.

TOLEDO FILHO, D.V. de; PARENTE, P.R. Aspectos da arborização urbana de uma cidade do interior. In: ENCONTRO NACIONAL SOBRE ARBORIZAÇÃO URBANA, 1., Porto Alegre, 1985. Anais. Porto Alegre: Secretaria Municipal do Meio Ambiente, 1985. p.155-162. 